\title{
Glacial to interglacial primary production and El Niño-Southern Oscillation dynamics inferred from coccolithophores of the Santa Barbara Basin
}

\author{
Michaël Grelaud, ${ }^{1}$ Luc Beaufort, ${ }^{1}$ Stéphanie Cuven, ${ }^{2}$ and Noëlle Buchet ${ }^{1}$ \\ Received 28 November 2007; revised 5 November 2008; accepted 17 November 2008; published 24 January 2009.
}

[1] We investigate the long-term stability of El Niño-Southern Oscillation and Pacific Decadal Oscillation based on the examination of coccolithophore assemblages in a largely laminated $35 \mathrm{ka}$ sedimentary record, retrieved in the Santa Barbara Basin (core MD02-2503). At a centennial scale coccolith assemblages indicate low primary production in the basin from 35 to 11.5 ka B.P., whereas the Holocene is characterized by high-productivity conditions. This pattern demonstrates the influence of the glacial-interglacial cycles on productivity and, by inference, on the nutrient supply by the upwelling cell off Point of Conception. On a shorter scale, laminations associated with Dansgaard-Oeschger events appear to be due to an injection of poorly oxygenated waters in the deepest part of the basin rather than anoxia due to high primary production. A seasonal sampling in seven laminated sections (spanning from 20 to 220 years) extracted from Holocene, Bølling-Allerød, and DansgaardOeschger event 3 indicates El Niño probably existed continuously during the last $28 \mathrm{ka}$. The frequency of El Niño

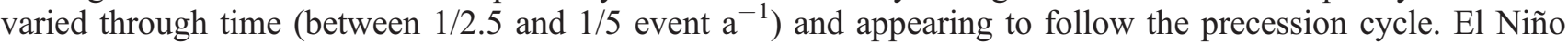
exhibits higher (lower) frequencies when the precession values are lower (higher). Finally, the Holocene is characterized by a decrease in El Niño's frequencies due to the reinforcement of El Niño through this period.

Citation: Grelaud, M., L. Beaufort, S. Cuven, and N. Buchet (2009), Glacial to interglacial primary production and El NiñoSouthern Oscillation dynamics inferred from coccolithophores of the Santa Barbara Basin, Paleoceanography, 24, PA1203, doi:10.1029/2007PA001578.

\section{Introduction}

[2] The El Niño-Southern Oscillation (ENSO) originates in the tropical Pacific Ocean. It is one of the most important sources of global and inter-annual climate variability. ENSO is the primary source of year-to-year variations in tropical sea surface temperature [Philander, 1983] and its variability depends on oceanic and atmospheric processes affecting both the eastern and western parts of the Pacific Ocean. It is an oscillating system characterized by pseudo-periodicities ranging from 2 to $7-8$ years, but usually centered on the $3-5$ year band [Cane and Zebiak, 1985]. Unusually strong El Niño events of the two last decades (1982/1983 and 1997/ 1998) had widespread ecological, social and economic impacts, which have led to a strong increase in societal concern. During an El Niño event (warm phase) trade winds are weaker, inducing an eastward transfer of warm waters leading to a deepening of the thermocline in the eastern part of the tropical Pacific. Therefore, upwelling along the North America western coast is reduced, inhibiting primary production [Lange et al., 1997; Kincaid et al., 2000; Black et al., 2001].

[3] Coupled to ENSO, but on a longer scale, the Pacific Decadal Oscillation (PDO) is a phenomenon that presents characteristics similar to ENSO. During its negative phase, a cool wedge of low sea-surface temperatures/heights settles

${ }^{1}$ CEREGE, Université Aix Marseille, CNRS, Aix-en-Provence, France.

${ }^{2}$ INRS-ETE, Université du Québec, Quebec, Quebec, Canada

Copyright 2009 by the American Geophysical Union. 0883-8305/09/2007PA001578 in the eastern equatorial Pacific. A warm horseshoe pattern of high sea-surface heights is present in the north, west and southern Pacific. The opposite occurs during its positive phase as the west Pacific Ocean becomes cooler and the east warmer. The PDO pseudo-period is of approximately 20 to 30 years [Mantua and Hare, 2002]. This phenomenon may amplify El Niño events such as in 1982-1983 and 19971998, when the PDO was in a positive phase or reduced its impact such as in 2002/2003, when the PDO was in a negative phase.

[4] ENSO cycles are found both in oceanic and continental records, going back $130 \mathrm{ka}$ [Tudhope et al., 2001]: in these records ENSO is always less frequent during the early and middle Holocene. Modeling indicate that it might result from reduced amplification in the late summer and early fall, and is a consequence of the altered mean climate in response to boreal summer perihelion [Cane, 2004].

[5] The aim of this study is to characterize possible longterm changes of ENSO and PDO in North Eastern Pacific in multiple time slices since $28 \mathrm{ka}$. We analyzed coccolith assemblages in laminated sediment of the Santa Barbara Basin (SBB). Coccoliths are the calcified plates forming the exoskeleton of the coccolithophores. These unicellular pelagic algae represent a large proportion of the world oceans nannophytoplankton and play a significant role in the carbon cycle. Assemblages specific composition varies in relation to physico-chemical parameters in the photic zone and therefore coccolithophores are reliable tracers of paleoenvironmental conditions. The coccolithophores are widely used to reconstruct paleoecological and paleoceanographical changes 


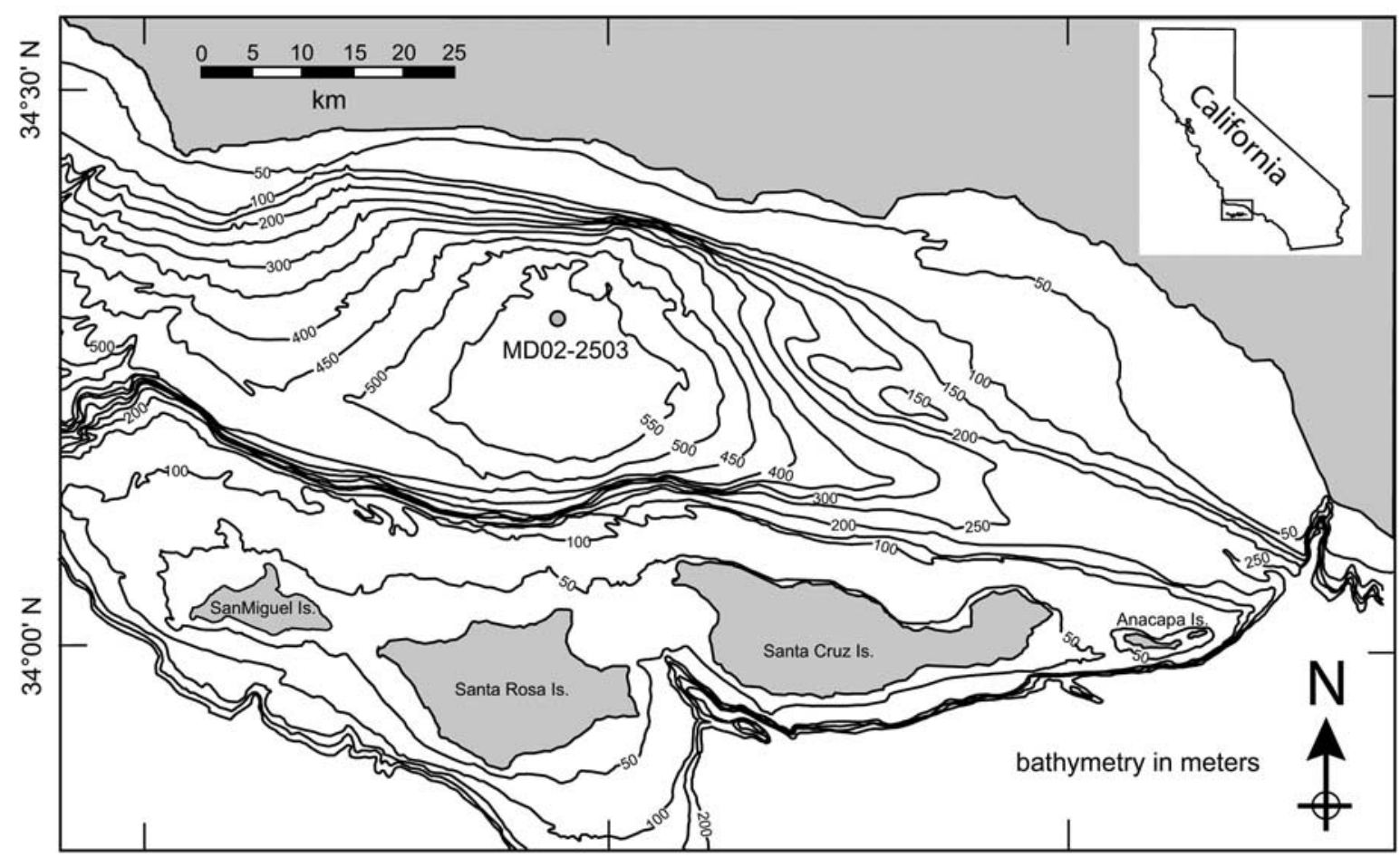

Figure 1. Location of core MD02-2503.

[McIntyre and Be, 1967; Okada and McIntyre, 1979; Roth and Coulbourn, 1982; Samtleben and Schroder, 1992; Giraudeau et al., 1993; Beaufort et al., 1997; Andruleit and Baumann, 1998; Kinkel et al., 2000; Nederbragt et al., 2008]. Their relative abundance, in the sediment of the SBB is diagnostic of past primary production (PP) and by inference of climatic conditions which have influenced coccolithophore assemblages [Ziveri et al., 1995b; De Bernardi et al., 2005]. Because of their abundance and small size, it is possible to sample them inside and between laminae, and hence to reach the infra-annual resolution needed to study ENSO dynamics.

\section{Material and Methods}

\subsection{Core Characteristics}

[6] A $\sim 47 \mathrm{~m}$ giant piston-core (IMAGES MD02-2503), taken from the R/V Marion Dufresne in SBB (Figure 1), was retrieved during the MONA IMAGES VIII campaign [Beaufort, 2002]. Core MD02-2503 is essentially composed of silty clays, nannofossil silty clays and nannofossil clays. The core is characterized by the presence of extended laminated sequences, in the upper $15 \mathrm{~m}$ and between 18 and $22 \mathrm{~m}$. These laminae seems to be due to anoxic conditions, prevailing in the deepest part of SBB that inhibits bioturbation by benthic organisms [Behl and Kennett, 1996; van Geen et al., 2003].

\subsection{Age Model}

[7] Core MD02-2503 was retrieved at the location of Ocean Drilling Program (ODP) site 893. Consequently, there is strong similarity between the ODP 893 and MD02-2503 oxygen isotopic records [Hill et al., 2006] and magnetic susceptibility [Blanchet, 2006]. Because of these similarities, and the presence of laminated sections, it was possible to correlate MD02-2503 to ODP 893, and then use the ODP 893 age scale which is based on $70{ }^{14} \mathrm{C}$ dates for the last $30 \mathrm{ka}$ [Hendy et al., 2002]. Alterning of laminated/bioturbated sediments in SBB were previously used as of climatic changes indicators similar to those recorded in the Greenland ice cores [Behl, 1995; Behl and Kennett, 1996]. The intervals of well preserved laminae correspond to warm interstadial/ interglacial record in Greenland ice cores [Behl, 1995; Behl and Kennett, 1996]. The chronology based upon these tie points present downward the last deglaciation, yields sedimentation rates of $\sim 135 \mathrm{~cm} / \mathrm{ka}$ for the past $32 \mathrm{ka}$ [Hill et al., 2006]. The chronology of the Holocene was completed with five accelerator mass spectrometry ${ }^{14} \mathrm{C}$ ages on mixed planktonic foraminifera of core MD02-2503 (Table 1). This chronology yields sedimentation rates of $\sim 142 \mathrm{~cm} / \mathrm{ka}$ indicating minimal core "stretching" (sometimes associated with piston coring [Thouveny et al., 2000]) when compared to ODP 893.

\subsection{Sampling}

[8] Two time resolutions were achieved in this study. First, sediments were collected at a $20 \mathrm{~cm}$ sampling step to reach a secular resolution (110 years) in the coccoliths assemblages. Then, in seven well preserved laminated sections two samples per lamina were taken: one in the pale band and the other in the dark band. The pale bands correspond to biogenic summer deposits and the dark bands 
Table 1. Radiocarbon Ages Used in MD02-2503 Chronology

\begin{tabular}{|c|c|c|c|c|c|}
\hline Depth in Core $(\mathrm{cm})$ & AMS ${ }^{14} \mathrm{C}$ Age & Error $^{\mathrm{a}}$ & Calendar Age ${ }^{\mathrm{b}}$ (years) & Foraminifera $^{c}$ & Accession Number \\
\hline 3 & 895 & 30 & 237 & Planktonic & SacA 7095 \\
\hline 50.5 & 1035 & 25 & 396.5 & Planktonic & SacA 7096 \\
\hline 300.5 & 2790 & 30 & 2201 & Planktonic & SacA 7097 \\
\hline 809.5 & 7090 & 50 & 7341 & Planktonic & SacA 7098 \\
\hline 1496.5 & 10125 & 50 & 10744 & Planktonic & SacA 7099 \\
\hline
\end{tabular}

to detritic winter deposits [Behl, 1995]. As such a semiannual resolution was reached.

[9] The seven sections represent time-windows ranging from 20 to 220 years. Four sections have Holocene ages $(0.9,3.4,6.1$ and $8.8 \mathrm{ka}$ B.P.) and are respectively $22,79.5$, 22.5 and 63.5 years long. Two other sections have BøllingAllerød ages (12.6 and 14 ka B.P.) and span 112.5 and 220 years. A section spanning 132 years was sampled in laminated sediments dated from about 27.7 ka B.P., during the Dansgaard-Oeschger event 3.

[10] A smear slide was prepared for each sample. In each slide, forty view fields of a light microscope were grabbed by a digital camera (Micam for the low-resolution series and Spot insight for the high-resolution series). Each frame was analyzed by an automated system of coccolith recognition (Système de Reconnaissance Automatique de Coccolithes (SYRACO)) [Dollfus and Beaufort, 1999; Beaufort and Dollfus, 2004]. This system is able to recognize 14 different coccolith species. More than $96 \%$ of the assemblages were composed by five species: Emiliania huxleyi, Florisphaera profunda, Gephyrocapsa ericsonii, Gephyrocapsa muellerae and Gephyrocapsa oceanica. An average of 400 individuals, including the five dominant species, was counted for each sample. SYRACO main error is that it includes non coccolith specimens in the counts, but this error is reproducible [Beaufort and Dollfus, 2004]. In consequence we applied a correction coefficient to each species in order to take into account the addition of noncoccoliths produced by the software. For the centennial resolution record, we present results obtained on two dominant species $E$. huxleyi and F. profunda and on two sub dominant species G. muellerae and $G$. oceanica. For the seasonal resolution records the results were obtained on the two dominant species $E$. huxleyi and F. profunda as well as on G. oceanica. Emiliania huxleyi is here taken in a broad sense because it may integrate other small placoliths of the genus Reticulofenestra or Gephyrocapsa. However, this error is estimated to be of a few \% after comparative counts on a standard error of the mean.

[11] Coccoliths flux (see auxiliary material Data Set S1) was estimated from the centennial resolution suite of samples. ${ }^{1}$ Estimations were based on counts of the number of coccoliths in 50 successive fields with an optical microscope at a $\times 500$ magnification. Samples were prepared as follows: about $0.01 \mathrm{~g}$ of sediment were diluted in $100 \mathrm{~mL}$ of

\footnotetext{
${ }^{1}$ Auxiliary materials are available at $\mathrm{ftp} / / \mathrm{ftp}$.agu.org/apend/pa/ $2007 \mathrm{pa} 001578$.
}

tap-water and then filtered through a $0.45 \mu \mathrm{m}$ cellulosic membrane. A quarter of the membrane was mounted with Canadian balsam. The number of coccoliths per gram of sediment was calculated as follows:

$$
A=\frac{N c \times S f}{N o \times S o \times W S}
$$

where $A$ is the number of coccoliths per gram of sediment, $N c$ is the number of coccoliths counted, $S f$ is the surface of the membrane $\left(1240 \mathrm{~mm}^{2}\right)$, No is the number of view field counted, So is the surface of a view field $\left(0.04 \mathrm{~mm}^{2}\right)$ and $W S$ the weight of sediment filtered on the membrane in gram. The flux is estimated by multiplying $A$ by the sedimentation rate (calculated from the age model) and the wet bulk density of the sediment given by shipboard data [Beaufort, 2002].

\subsection{Modern Climatic Data}

[12] To understand the possible influence of the PDO and El Niño on the sea surface temperatures of the SBB, we calculate the monthly sea surface temperature anomalies of SBB by taking out the monthly sea surface temperature (SST) mean for the last century. The SST of SBB are extracted from the extended reconstruction of global SST [Smith and Reynolds, 2003] and derived from the latest version of Comprehensive Ocean-Atmosphere Data Set (COADS) release 2 [Woodruff et al., 1998]. It is based on combined satellite and in situ analysis [Reynolds et al., 2002]. From 1900 to 1950 (period of non routinely data acquisition), the data cover an area of $1^{\circ} \times 1^{\circ}$ centered on $120^{\circ} \mathrm{N}, 34^{\circ} \mathrm{W}$. The mean number of measure per month goes from 2 to $4(1900-1930)$ to more than $35(1930-1950)$. It is then possible to compare the monthly sea surface temperature anomalies of SBB to the extended Nino3 index [Kaplan et al., 1998; Reynolds et al., 2002] (Figure 2a), which covers a large area of the equatorial Pacific $\left(5^{\circ} \mathrm{N}-5^{\circ} \mathrm{S}\right.$; $\left.90^{\circ} \mathrm{W}-150^{\circ} \mathrm{W}\right)$. It has been shown that during El Niño years, the tropical convection center moves to the central and eastern equatorial Pacific. As a result the North Pacific High is weaken, inducing the warming up of the California borderlands through the intensification of the southern California Countercurrent [Bograd and Lynn, 2001]. The monthly SST anomalies of the SBB were also compared to the PDO index [Mantua et al., 1997; Zhang et al., 1997] (Figure 2a), which reflects SST anomalies in the North Pacific Ocean, poleward of $20^{\circ} \mathrm{N}$, including the SBB. SBB Sea Surface Temperature data $\left(34^{\circ} \mathrm{N} ; 120^{\circ} \mathrm{W}\right)$ and extended Nino3 index 

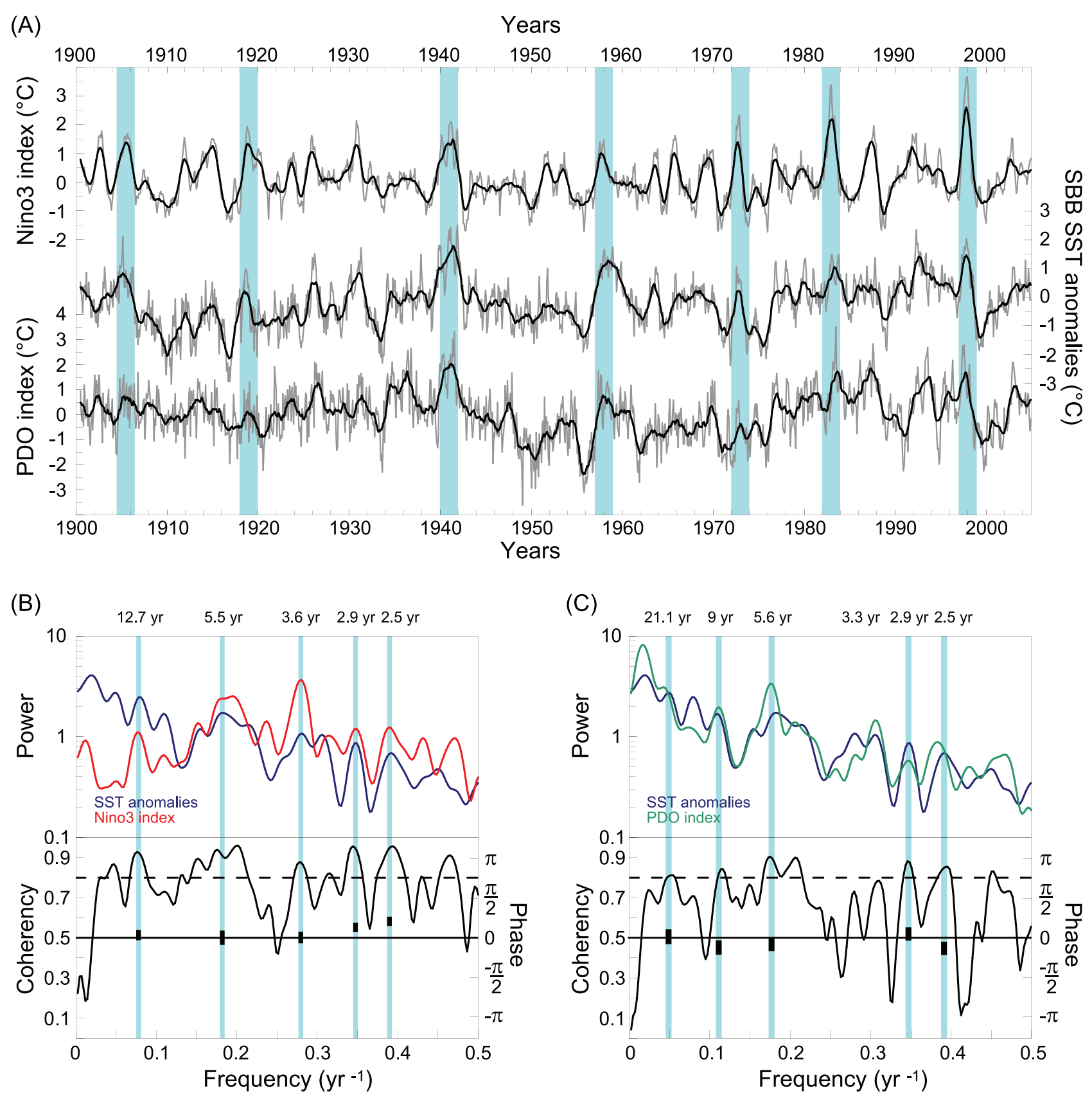

Figure 2. Modern climatic variability over the Santa Barbara Basin. (a) From top to bottom, extended Nino3 index, Santa Barbara SST anomalies and PDO index. The heavy black lines represent 13 months average smoothing. (b) Cross spectral analysis of extended Nino3 index (red line) versus SBB SST anomalies (blue line) (band width $=0.028$ ). (c) Cross spectral analysis of PDO index (green line) versus SBB SST anomalies (blue line) (band width = 0.028). The coherency is given by the black line (significant over 0.8 at 95\%) and the phase by the little black rectangle.

data are available via the International Research Institute/ Lamont-Doherty Earth Observatory Climate Data Library Web site: http://iridl.ldeo.columbia.edu/SOURCES/.NOAA/ .NCDC/.ERSST/.version1/.SST http://iridl.ldeo.columbia. edu/SOURCES/.Indices/.nino/.EXTENDED/.NINO3/.

[13] PDO index data [Mantua et al., 1997; Zhang et al., 1997] are available via the Joint Institute for the Study of the
Atmosphere and Ocean Web site: http://jisao.washington. edu/pdo/PDO.latest.

\subsection{Spectral Analyses}

[14] We compared modern climatic data by performing cross-spectral analyses between SBB SST anomalies and extended Nino3 index and between SBB SST anomalies and 
PDO index (Figures $2 \mathrm{~b}$ and 2c). We used the BlackmanTuckey and Cross-Blackman-Tuckey methods provided in the Analyseries software package [Paillard et al., 1996]. By this method, we obtained spectra of coherency and phase allowing a proper comparison between the temporal variability in extended Nino3 index, PDO index and SSB SST anomalies (Figures $2 \mathrm{~b}$ and $2 \mathrm{c}$ ).

[15] As some of the seven high-resolution records did not present evenly spaced data, some laminae being too thin to be sampled, some others too wide were sampled several times; we rather used the REDFIT software [Schulz and Mudelsee, 2002] to perform spectral analyses. This program estimates the spectra using the Lomb-Scargle Fourier Transform (LSFT) for unevenly spaced data. The oversampling factor (OFAC), which determines how many frequencies are investigated in the LSFT, was set to 4 for all data analyzed. We performed Welch-Overlapped-Segment-Averaging (WOSA) procedure with 50\% overlapped segments for univariate spectra. Linear detrending was used for each segment and a Welch I window type is employed to reduce spectral leakage. The univariate spectra were bias-corrected using 1000 Monte-Carlo simulations, which is a standard number of simulations. The red-noise alternative is upper 80, 90, 95 and 99\% Monte-Carlo bound from a first-order autoregressive (AR1) process (for more details concerning these parameters, see Schulz and Stattegger [1997]).

[16] For the seven seasonal resolution records, spectral analyses were first conducted on the relative abundances of each species (E. huxleyi, F. profunda and G. oceanica) then on the detrended relative abundances of each species. The first analysis highlights the low frequencies, associated to PDO, and the second higher frequencies, associated to ENSO. To detrend the relative abundances of E. huxleyi, F. profunda and G. oceanica, we removed the first Singular Spectrum Analysis (SSA) [Vautard and Ghil, 1989], which unravels the information embedded in a time series by decomposing the sequence into elementary patterns of behavior in time and spectral domains. It uses "dataadaptive filters" that help in separating the time series into statistically independent components, which can be classified as trends, deterministic oscillations or noise. We used software Analyseries [Paillard et al., 1996] to perform the SSA.

\section{Climatic Variability Over the Santa Barbara Basin}

[17] The Santa Barbara Basin is located beneath the influence of the California Current. The strength of this current is controlled by changes in wind speed and direction, in relation to the seasonal position of the North Pacific High and the adjacent continental thermal low. Strong upwelling develops during spring and early summer under northerly wind regime [Hendershott and Winant, 1996; Harms and Winant, 1998; Longhurst, 1998], whereas during fall and winter, northerly winds and upwelling strength weaken [Soutar and Crill, 1977; Thunell et al., 1995]. The California Current is also influenced by El Niño: during an event the North Pacific High is weaken leading to a weakening of the California Current [Bograd and Lynn, 2001].
[18] Over the last century, the site appears to be plainly influenced by both ENSO and PDO as suggested by modern climatic data (Figure 2a). The three parameters present the same range of variability. The SBB SST anomalies, the extended Nino3 index and the PDO index are well correlated $\left(\mathbf{R}_{\mathrm{SBB} \text { SSTA/Nino } 3}=0.53\right.$ and $\left.\mathbf{R}_{\mathrm{SBB} \text { SSTA/PDO }}=0.49\right)$. In particular peaks of Nino3 and PDO are represented in positive SST anomalies, and this is particularly true for the strongest El Niño events recorded through the last century (Figure 2a). Moreover, the SBB SST anomalies do not lag behind Nino3 and PDO indexes as suggested by phase spectra (Figures $2 \mathrm{~b}$ and $2 \mathrm{c}$ ). Cross-spectral analyses show that Nino3 index and SBB SST anomalies present coherent periodicities around 2.5, 2.9, 3.6 and 5.5 years (Figure 2b); whereas PDO index and SBB SST anomalies exhibit coherent periodicities around 2.5, 2.9, 3.3, 5.6, 9 and 21.1 years (Figure 2c). ENSO high-frequency (2.5- to 3-year) components are typically associated with the lifetime of ENSO events and the El Niño/La Niña alternation. ENSO low-frequency components (3- to 7-year) are typically associated with the spacing of two large El Niño events [Zebiak and Cane, 1987; Graham and White, 1988]. Low frequencies ( $>20$ years) observed in the SBB SST anomalies are typically associated to the Pacific Decadal Oscillation variability.

\section{Coccolithophores: Ecology, Seasonality, and Response to El Niño Conditions in the SBB}

\subsection{Coccolithophores Ecology}

[19] Emiliania huxleyi is one of the most ubiquitous and tolerant coccolithophore species. It produces large phytoplankton bloom at mid latitudes [Holligan et al., 1993; Brown and Yoder, 1994], when nutrient enrichment prevails such as in coastal upwelling areas or marginal seas [Okada and Honjo, 1975; Brand, 1994; Broerse, 2000]. A recent study show that $E$. huxleyi would not be indicative of upwelling processes but should be more regarded as an indicator of stable regimes with relatively high nutrient availability [Andruleit and Rogalla, 2002]. Gephyrocapsa oceanica is largely found in tropical and subtropical areas [McIntyre et al., 1970; Andruleit et al., 2000, 2003] and preferentially thrive in high-nutrient environments such as upwelling areas or continental shelves [Mitchellinnes and Winter, 1987; Houghton and Guptha, 1991; Giraudeau, 1992; Young, 1994]. Gephyrocapsa muellerae appears to be related to moderately productive cool surface waters with mean temperatures lower than $20^{\circ} \mathrm{C}$ [Bollmann, 1997; Flores et al., 1997; Knappertsbusch et al., 1997]. These three species thrive in the upper photic zone. In contrast F. profunda dominates the coccolithophores communities of the lower photic zone of tropical to subtropical region [Okada and Honjo, 1973; Reid, 1980; Okada and Matsuoka, 1996; Takahashi and Okada, 2000; Malinverno et al., 2003]. This species lives below the deep chlorophyll maximum [Okada and Honjo, 1973]. Its relative abundance increases in oligotrophic area [Beaufort et al., 1997] or when the upper photic zone is depleted in nutrients and the nutricline is deep [Molfino and McIntyre, 1990]. Conversely, the relative abundance of this species tends to decrease when the 
nutricline rises allowing an increase of the primary production in the upper photic zone.

\subsection{Modern Coccolithophores Seasonality in the SBB}

[20] In their study, De Bernardi et al. [2005] showed that during the pre-El Niño period (no El Niño or La Niña conditions), E. huxleyi and G. oceanica are more abundant during winter when the upwelling is weakened. This is not necessarily contradictory to the fact that these species thrive in rich nutrients environments as SBB waters exhibit high nutrient concentration in winter [Shipe et al., 2002], probably corresponding to the stable regime described by Andruleit and Rogalla [2002]. Nevertheless, the abundance of E. huxleyi remains high during summer, whereas these of $G$. oceanica decreased slightly representing only $\sim 3 \%$ of the assemblage [De Bernardi et al., 2005]. It seems that a relatively high nutrient supply is not sufficient to the development of this species, at least in the SBB. Florisphaera profunda abundances start to increase in early summer and are maximal in fall. Such seasonality was also observed in North Atlantic: E. huxleyi and G. oceanica present their lowest abundance during late summer and early fall whereas F. profunda was more productive during summer and early fall [Okada and McIntyre, 1979; Haidar and Thierstein, 2001]. Similarly, off the west European continental margin, F. profunda is more productive during fall [Beaufort and Heussner, 2001].

\subsection{Influence of EI Niño on Coccolith Assemblages in SBB}

[21] In the SBB between 1997 and 1998, E. huxleyi dominated the coccolith assemblage before and during El Niño event [De Bernardi et al., 2005], even if its abundance decreased slightly during the onset of the event. In contrast, the relative abundance of $F$. profunda increased slightly during the onset, when SBB waters exhibit very low nutrient concentrations [Shipe et al., 2002]. Gephyrocapsa oceanica increased significantly at the onset of the event and its abundance was correlated with higher temperature in the upper water column $\left(3^{\circ} \mathrm{C}\right.$ higher than during non-El Niño period) [De Bernardi et al., 2005]. The authors concluded that high abundance of $G$. oceanica could be used as an indicator of strong paleo-El Niño in the SBB. During the weak El Niño event of 1992, Ziveri et al. [1995b] showed that the abundance of E. huxleyi tends to increase during the onset of the event in the San Pedro Basin ( 175 km southeast of SBB). Similar trends were observed by Broerse [2000] in the central tropical Pacific. Conversely, G. oceanica was less abundant during the weak 1992 event than during the strong 1997-1998 event. In the tropical Pacific abundance of $F$. profunda did not increased significantly during weak El Niño period [Broerse, 2000]. This species does not seem to be affected by El Niño events probably because it grows predominantly during summer in the SBB, while warm El Niño event will reach its onset during winter [McPhaden, 1999].

[22] Emiliania huxleyi, a very tolerant species, dominates largely coccolithophore assemblages in the SBB. Its relative abundance remains high during normal conditions (no El Niño or La Niña). During weak El Niño conditions its relative abundance could increase slightly as suggested by
Ziveri et al. [1995a]. It is only during a strong warm event (1997-1998) that its relative abundance decreased to the benefit of the warm water species G. oceanica [De Bernardi et al., 2005]. As E. huxleyi thrive in a large range of conditions in the SBB, we will use its relative abundance as a marker of normal conditions (no El Niño or La Niña) to moderate El Niño conditions. The relative abundances of G. oceanica will be used as indicator of strong El Niño conditions. Because the relative abundance of F. profunda does not appear to be strongly correlated to El Niño development in today's ocean, we cannot use this species as a proxy for El Niño intensity. At a secular scale we suggest however that in the SBB the relative abundance of $F$. profunda is responding to changes in nutrients availability as it is the case in the rest of the low-latitude oceans [Beaufort et al., 1997].

\section{Results}

[23] Recent radio carbon dating on different size fractions of the SBB sediments indicated that the ages of the fine grained particles are significantly older than the coarse fraction [Mollenhauer and Eglinton, 2007]. A lateral transport from the shelf of old fine particles could be evoked and could hamper any interpretation of coccoliths high-resolution records since this lateral transport could also include coccoliths. Several pieces of evidence indicate that this transport is not occurring: (1) Polarizing and scanning electron microscope observations of the sediment reveal that coccoliths represent only a small fraction of the fine carbonate particles. (2) Coccoliths are pelagic phytoplankton and preferentially grow far from coastal areas. (3) The shelf is narrow in SBB suggesting that few coccoliths would be remobilized from the flanks. Therefore, the coccoliths contained in SBB sediments were likely produced above the basin rather than transported from the shelf. The fact that a seasonal cycle is observed in coccoliths assemblages tends to confirm the in situ development of coccolithophores.

\subsection{Coccolith Relative Abundances Record}

[24] The relative abundance of selected species observed in core MD02-2503 are very close to those observed in ODP site 893A, at least for the last $16 \mathrm{ka}$ [Nederbragt et al., 2008]. Emiliania huxleyi and F. profunda largely dominate $(>65 \%)$ the assemblages during the last $35 \mathrm{ka}$, while G. oceanica represents only $8.5 \%$ and G. muellerae less than $6.5 \%$ (Figures $3 \mathrm{~b}-3 \mathrm{e}$ ). The record can be subdivided into two distinct parts: the first one extending from 35 to $\sim 11.5$ ka B.P. where $F$. profunda dominates the assemblage and the second one from $\sim 11.5 \mathrm{ka}$ B.P. to the late Holocene where E. huxleyi dominates. Gephyrocapsa oceanica exhibits relatively low percentages $(>10 \%)$ during the last 35 ka B.P. Gephyrocapsa muellerae follow the same trend than E. huxleyi as it exhibits low relative abundances $(\sim 5 \%)$ from $35 \mathrm{ka}$ B.P. to $11.5 \mathrm{ka}$ B.P. and higher relative abundance $(\sim 8 \%)$ during the Holocene (Figure 3e). Florisphaera profunda can be used as a proxy for paleoprimary production [Beaufort et al., 1997]. Estimates of Primary Production for the Holocene, using the equation from Beaufort et al. [1997], fluctuates around $240 \mathrm{gC} / \mathrm{m}^{2} / \mathrm{a}$ with a standard deviation (STD) of $38 \mathrm{gC} / \mathrm{m}^{2} / \mathrm{a}$. Between 35 and $11.5 \mathrm{Ka}$ B.P. PP 


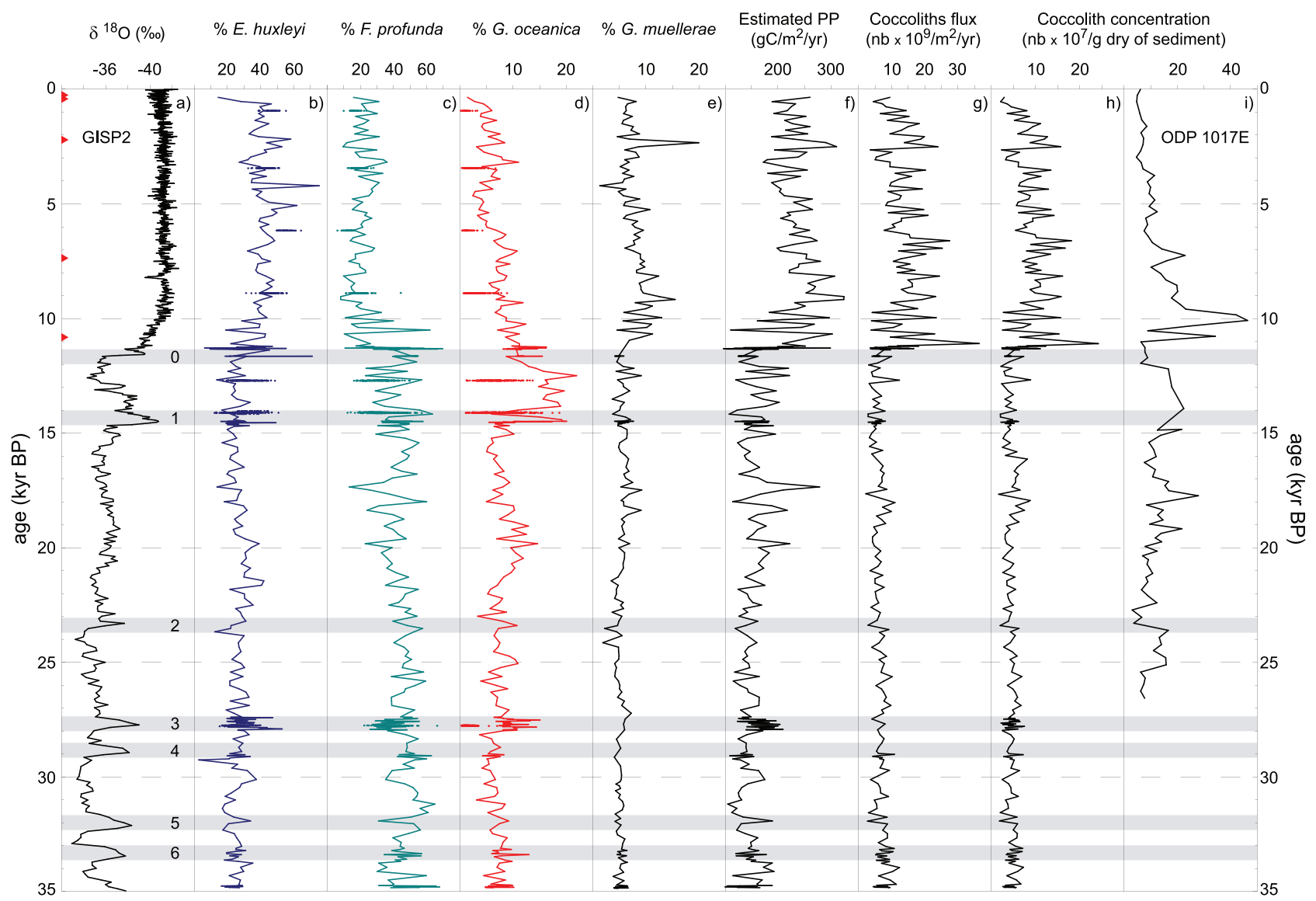

Figure 3. (a) GISP $\delta^{18} \mathrm{O}$ [Grootes and Stuiver, 1997]; relative abundance (\%) of (b) E. huxleyi, (c) F. profunda, (d) G. oceanica, and (e) G. muellerae; (f) estimated primary production ( $\left(\mathrm{gC} / \mathrm{m}^{2} / \mathrm{a}\right)$; (g) coccolith flux $\left(\mathrm{nb} \times 10^{9} / \mathrm{m}^{2} / \mathrm{a}\right)$; (h) coccolith concentration in core MD02-2503 (nb $\times 10^{7} / \mathrm{g}$ of dry sediment); (i) coccolith concentration in ODP $1017 \mathrm{E}$ (nb $\times 10^{7} / \mathrm{g}$ of dry sediment) [Tanaka and Tada, 2000]. Colored dots show the seven high-resolution series. Red triangles, ${ }^{14} \mathrm{C}$ dating; gray bands, Dansgaard-Oeschger events.

estimates decrease to $150 \mathrm{gC} / \mathrm{m}^{2} / \mathrm{a}\left(\mathrm{STD}=26 \mathrm{gC} / \mathrm{m}^{2} / \mathrm{a}\right)$ (Figure 3f). The coccolith flux in MD02-2503 shows the same trend as that of the estimated PP with a sharp increase at $11.5 \mathrm{Ka}$ B.P. Prior to $11.5 \mathrm{Ka}$, the average flux is $5.20 \times 10^{9}$ Coccoliths $/ \mathrm{m}^{2} / \mathrm{a}\left(\mathrm{STD}=1.74 \times 10^{9}\right.$ Coccoliths $\left./ \mathrm{m}^{2} / \mathrm{a}\right)$ and reaches $9.85 \times 10^{9}$ Coccoliths $/ \mathrm{m}^{2} / \mathrm{a}$ during the Holocene $\left(\mathrm{STD}=4.83 \times 10^{9}\right.$ Coccoliths $\left./ \mathrm{m}^{2} / \mathrm{a}\right)$ (Figure $\left.3 \mathrm{~g}\right)$. Coccolith concentrations in MD02-2503 (Figure 3h) are compared to concentrations in the ODP site 1017E [Tanaka and Tada, 2000] off Point of Conception (Figure 3i) on the Santa Lucia Slope ( $\sim 100 \mathrm{~km}$ northwest of MD02-2503). Before $11.5 \mathrm{Ka}$, the average coccolith concentration in MD02-2503 is three times lower $\left(4.47 \times 10^{7}\right.$ coccoliths/g of dry sediment; STD $=$ $1.37 \times 10^{7}$ coccoliths/g of dry sediment) than in ODP site $1017 \mathrm{E}\left(11.79 \times 10^{7}\right.$ coccoliths/g of dry sediment; STD = $4.94 \times 10^{7}$ coccoliths/g of dry sediment) (Figures $3 \mathrm{~h}$ and $3 i)$. In both record, the concentrations increase during the Holocene to reach an average concentration of $8.25 \times 10^{7}$ coccoliths $/ g$ of dry sediment $\left(\mathrm{STD}=4.07 \times 10^{7}\right.$ coccoliths $/ \mathrm{g}$ of dry sediment) in MD02-2503 and $12.99 \times 10^{7}$ coccoliths $/ g$ of dry sediment $\left(\mathrm{STD}=9.45 \times 10^{7}\right.$ coccoliths $/ \mathrm{g}$ of dry sediment) in ODP site 1017E (Figures $3 \mathrm{~h}$ and 3i).

[25] The relative abundances of E. huxleyi, $F$. profunda and $G$. oceanica in the seven seasonal resolution records fall in the same range of values than in the centennial resolution sample series (Figures $4 \mathrm{a}-4 \mathrm{c}$ ). However, G. oceanica exhibits values slightly below those in the low-resolution record, probably because we used two different digital cameras and two different Artificial Neural Network training of SYRACO. This species is more abundant at glacialinterglacial transition around 14 and $12.6 \mathrm{ka} \mathrm{B.P.}$

\subsection{Coccolithophores Seasonality Inferred From High-Resolution Records}

[26] As the sampling into and between laminae yields to a semi-annual resolution in the seven high-resolution series, we could determine the seasonality of E. huxleyi, F. profunda and $G$. oceanica in core MD02-2503. When we compare assemblages specific composition between pale (summer) and dark (winter) bands, it appears that E. huxleyi is predominantly produced during winter (dark bands, Table 2) and 
(A) Holocene

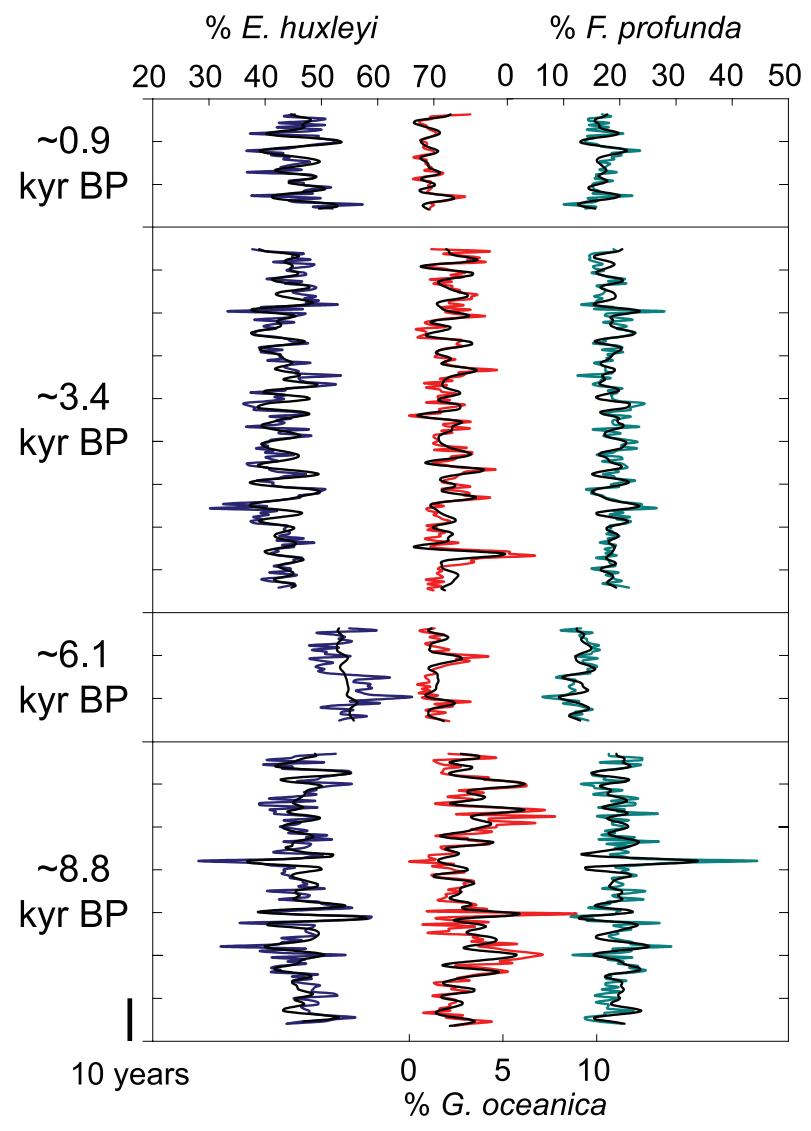

(C) Daansgard-Oeschger 3

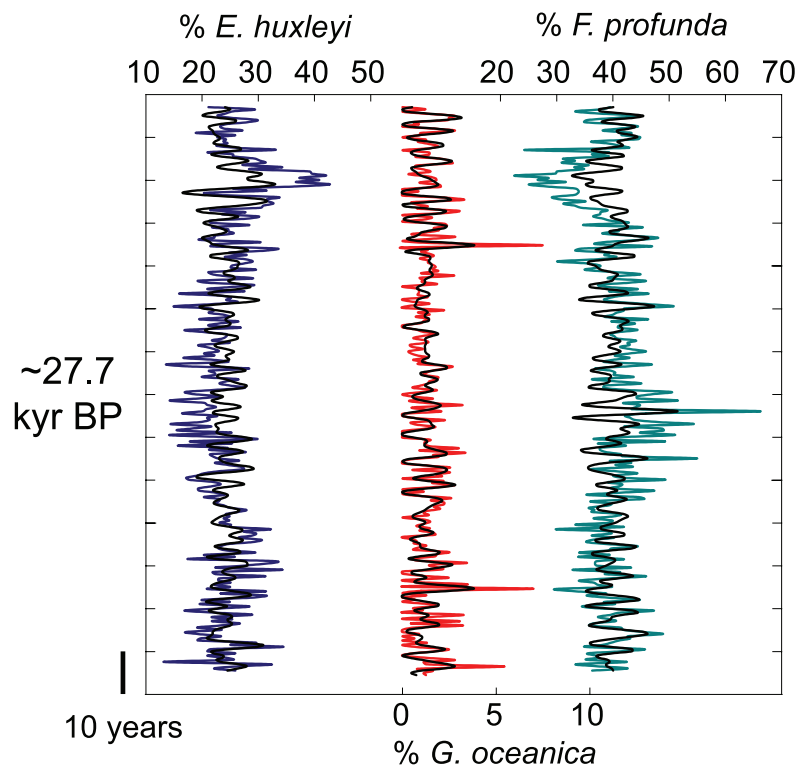

(B) Bolling-Allerod

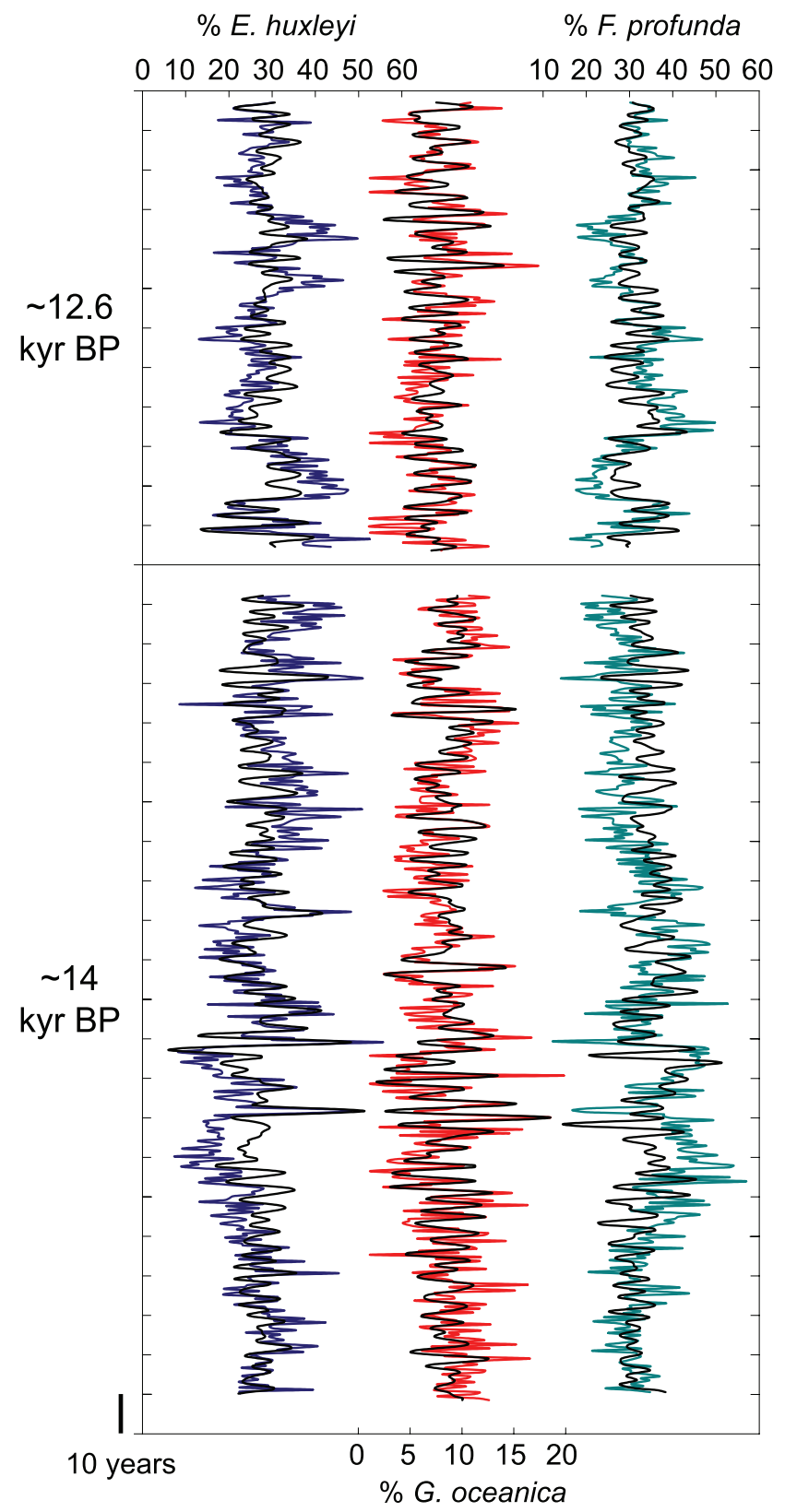

Figure 4. High-resolution series. Relative abundances of E. huxleyi (blue line), G. oceanica (red line), and F. profunda (green line) for (a) the Holocene, (b) the Bølling-Allerød, and (c) Dansgaard-Oeschger event 3. Heavy black lines represent Gaussian filters centered on a 2-7 year bandpath and on a 20-33 year bandpath. 
Table 2. Comparison of the Seasonality of E. huxleyi, F. profunda, and G. oceanica ${ }^{\text {a }}$

\begin{tabular}{|c|c|c|c|c|c|c|}
\hline \multirow[b]{2}{*}{ Ages (ka B.P.) } & \multicolumn{2}{|c|}{ E. huxleyi } & \multicolumn{2}{|c|}{ F. profunda } & \multicolumn{2}{|c|}{ G. oceanica } \\
\hline & PB (Summer) & DB (Winter) & PB (Summer) & DB (Winter) & PB (Summer) & DB (Winter) \\
\hline$\sim 0.9$ & -0.7 & 0.76 & 0.32 & -0.28 & -0.002 & 0.00006 \\
\hline$\sim 3.4$ & -0.25 & 0.3 & 0.19 & -0.25 & -0.05 & 0.02 \\
\hline$\sim 6.1$ & -0.66 & 0.76 & 0.5 & -0.58 & -0.08 & 0.06 \\
\hline$\sim 8.8$ & -1.02 & 0.98 & 0.5 & -0.48 & 0.09 & -0.08 \\
\hline$\sim 12.6$ & -0.24 & 0.18 & -0.15 & 0.18 & -0.07 & 0.08 \\
\hline$\sim 14$ & -1.88 & 1.86 & 0.74 & -0.73 & -0.56 & 0.57 \\
\hline$\sim 27.7$ & -0.19 & 0.15 & 0.17 & -0.15 & -0.05 & 0.06 \\
\hline
\end{tabular}

${ }^{\mathrm{a}}$ For each species, we compare the relative abundance obtained in a dark (pale) laminae to the averaged relative abundance of the two adjacent pale (dark) laminae. Positive values show that the species is predominantly produced during this type of laminae. PB, Pale Band; DB, Dark Band.

F. profunda during summer (pale bands, Table 2). It is more difficult to find a clear seasonal pattern for G. oceanica, since the difference between pale and dark band is very small (Table 2). For E. huxleyi and F. profunda, these results are in agreement with coccolithophore seasonality described by current observations [Okada and McIntyre, 1979; Beaufort and Heussner, 2001; Haidar and Thierstein, 2001; De Bernardi et al., 2005].

\subsection{Spectral Analyses}

[27] Spectral analyses performed on the relative abundances of E. huxleyi, F. profunda and $G$. oceanica show a periodicity of 20 to 30 years in the five longest series (Figure 5). This periodicity is comparable to that of the PDO [Mantua and Hare, 2002]. The series around 6.1 and 0.9 ka B.P. are too short to reveal this variability.

[28] Spectral analyses performed on the detrended relative abundance of E. huxleyi, F. profunda and G. oceanica present periodicities ranging from 2 to $7-8$ years comparable to modern ENSO variability (Figure 5). Emiliania huxleyi and G. oceanica exhibit a relatively similar range of periodicities (Figures 5a and 5b), whereas those of $F$. profunda differ slightly (Figure 5c). The relative abundance of $G$. oceanica and E. huxleyi exhibit shorter periodicities than those of F. profunda, during the Dansgaard-Oeschger event 3 ( 27.7 ka B.P.), the Bølling-Allerød ( 14 ka B.P.) and the late Holocene ( $\sim 0.9$ ka B.P.). During the early and midHolocene $(\sim 8.8,6.1$ and 3.4 ka B.P. $)$, the periodicities of $F$. profunda are shorter than those of $G$. oceanica and E. huxleyi.

\section{Discussion}

\subsection{Paleoproductivity in the SBB Through the Last 35 ka}

[29] When we compare the concentration of coccoliths in SBB and off Point of Conception (ODP site 1017E [Tanaka and Tada, 2000]) for the last $25 \mathrm{ka}$, it appears that the two curves are in the same range of variability (Figures $3 \mathrm{~h}$ and 3i). However, the concentrations are clearly higher in ODP site $1017 \mathrm{E}$ during the Last Glacial Maximum (LGM) and the deglaciation. During these periods, the sea level was lower than today. The Santa Barbara Channel was narrower delimited in the north by the continent and in the south by the Santa Rosae Island complex which includes today the modern San Miguel, Santa Rosa, Santa Cruz and Anacapa Islands [Kennett and Ingram, 1995b]. As upwelling and circulation in SBB are closely tied to processes just outside the basin, off Point of Conception [Hendershott and Winant, 1996], and because sills were shallower and upwelling shut down [Hendy et al., 2004], the contribution of high-nutrient waters of the upwelling cell off Point of Conception to the $\mathrm{SBB}$ was reduced during those periods. We estimate that low coccolith concentrations in the SBB characterizing LGM and deglaciation reflect predominantly low in situ production linked to reduced nutrients supply. Conversely, at the end of the deglaciation, when the sea level rises, the upwelling cell resupplies the SBB. Coccolith concentrations increased around $11.5 \mathrm{ka}$ B.P. and remained high during the entire Holocene. SBB coccolith concentrations are very close to those observed at the ODP site 1017E (Figures $3 \mathrm{~h}$ and $3 \mathrm{i}$ ) during this period, suggesting that modern oceanography in SBB was established around $11.5 \mathrm{ka}$ B.P.

[30] Doose et al. [1997] showed that coastal upwelling in the region of the northeast Pacific off northern California $\left(41-33^{\circ} \mathrm{N}\right)$ was significantly reduced or even completely shutdown during the LGM. Paleoproductivity proxies (e.g., $\mathrm{CaCO}_{3} \%, \mathrm{C}_{\text {org }}$, biogenic opal, diatoms, alkenones, pollen or total organic carbon) [Gardner et al., 1997; Lyle et al., 2000; Barron et al., 2003] suggest that organic productivity along the California margin was lower during LGM and Younger Dryas (cold intervals) and higher during BøllingAllerød and Holocene (warmer intervals) [Dean, 2007]. For example, the upwelling cell off Point of Conception, which supplies the SBB, was activated during warm intervals and turned off during cool intervals [Hendy et al., 2004]. Consequently, oligotrophic conditions are expected in SBB during the LGM, as shown by low coccolith concentrations. This is confirmed by $F$. profunda which dominates the coccolithophores assemblages during these periods. At $\sim 11.5 \mathrm{ka}$ B.P., the conditions reversed as E. huxleyi becomes the dominant species, corresponding to the establishment of more eutrophic conditions in the SBB. Kennett and Ingram [1995a] argued that the laminated intervals in ODP 893 (Bølling-Allerød and probably Holocene) were the result of poorer oxygenated ventilation in SBB because there was no evidence for higher productivity notably $\%$ $\mathrm{C}_{\text {org }}$ concentrations remain constant [Gardner and Dartnell, 1995]. Primary Production, estimated from coccoliths during the last $35 \mathrm{ka}$ in SBB, clearly shows two distinct phases also recorded in the relative abundances of $E$. huxleyi and F. profunda (Figure $3 \mathrm{f}$ ). Prior to $11.5 \mathrm{Ka}, \mathrm{PP}$ is significantly lower than after (Figure $3 \mathrm{f}$ ). This period of low productivity 
A)

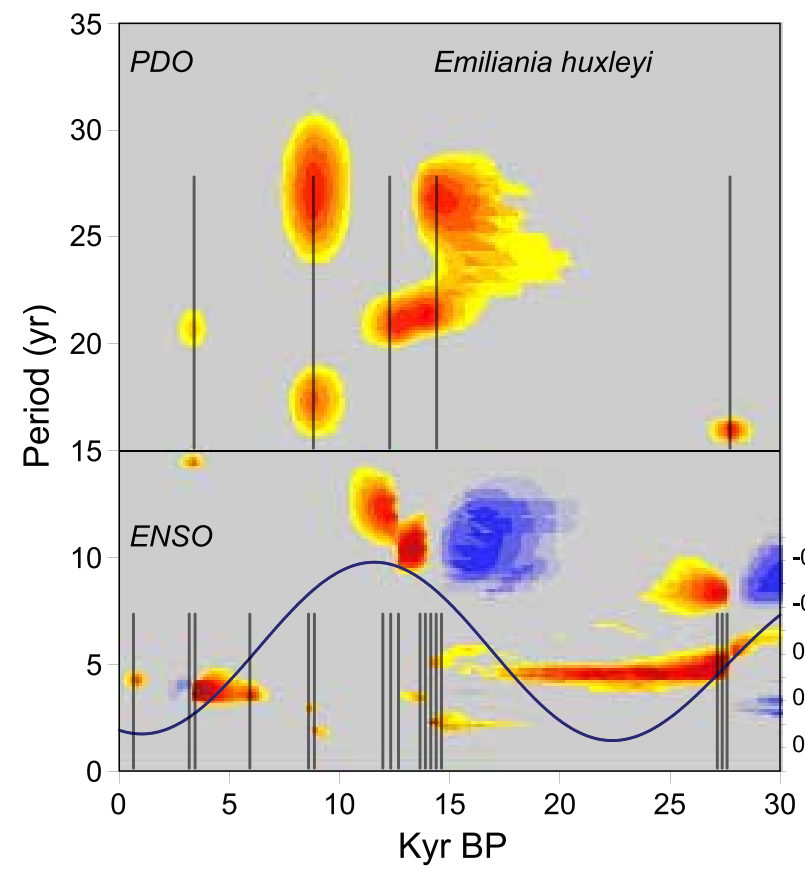

C)

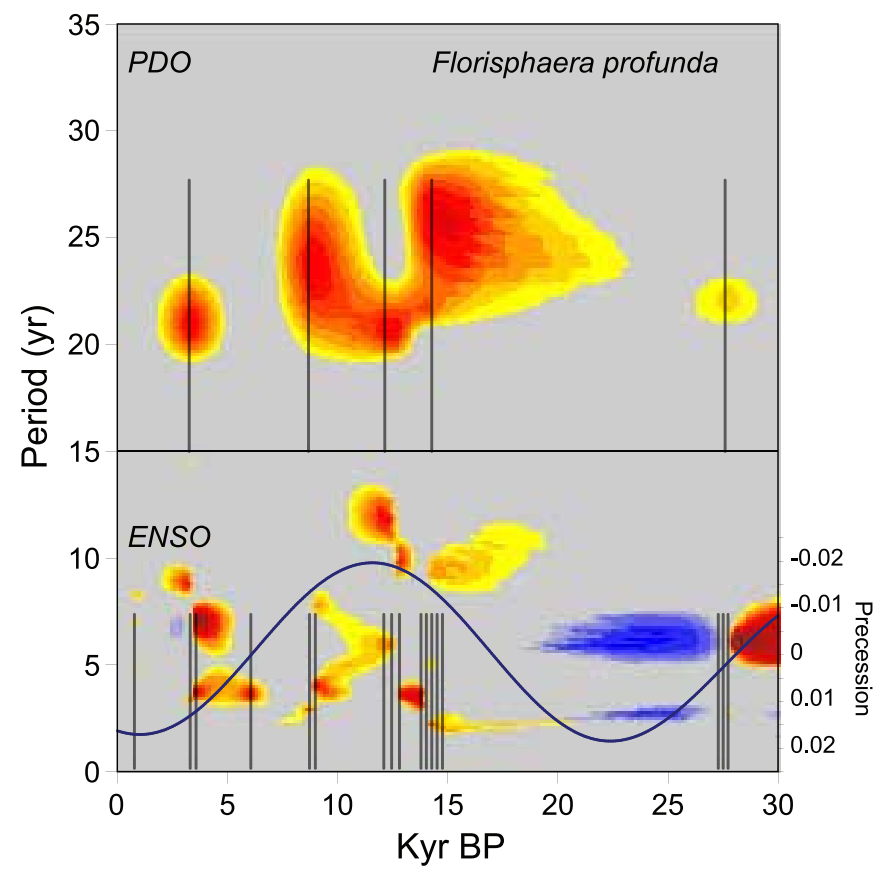

B)
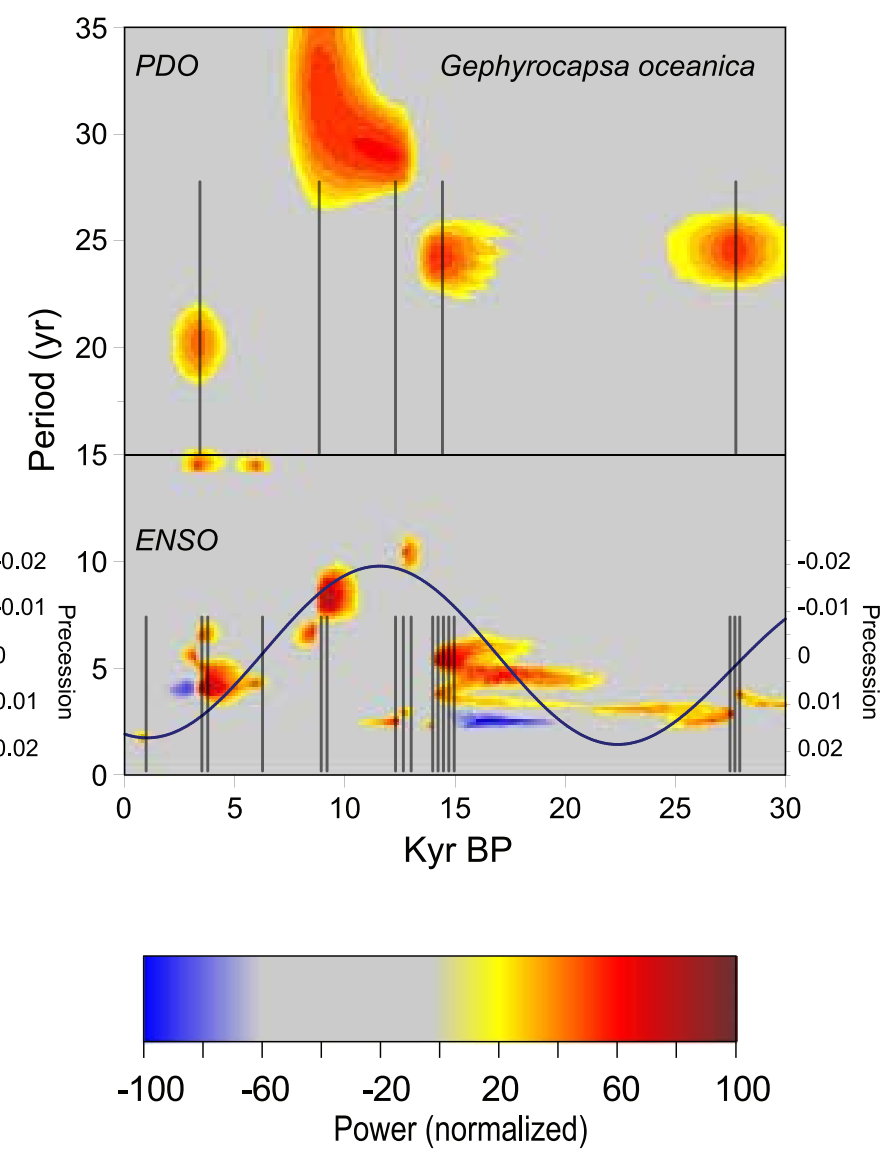

Figure 5. Spectral analyses performed on the relative abundances of (a) E. huxleyi, (b) G. oceanica, and (c) F. profunda. The top part of each graph presents the lower-frequency component (PDO). Spectra are estimated from the five longest high-resolution series. We used series of 220 years. The four shorter series were virtually elongated by zero-padding. The bottom part of each graph presents the higherfrequency component (ENSO). The spectra are estimated from the detrended seven high-resolution series. We used series of 50 years. The longest series were divided into 50 year series (without overlapping), and shorter series were virtually elongated by zero-padding. Each series of 220 or 50 years is represented by a thin black vertical line. Each of the power spectra was normalized in a way that the power estimate above an interval of confidence of $80 \%$ is positive. We use SURFER software to grid the data (kriging). The blue curves represent the precession [Laskar, 1990]. 
seems to be in agreement with the low PP estimates described by Kennett and Ingram [1995a] in bioturbated as well as in laminated intervals (Figure 3f). Nevertheless, the Holocene clearly appears to be more productive. The sharp and rapid increase of PP at $11.5 \mathrm{Ka}\left(200 \mathrm{gC} / \mathrm{m}^{2} / \mathrm{a}\right)$ occurred in less than a century. This increase is also observed in the coccolith flux (Figure $3 \mathrm{~g}$ ) attesting of more productive coccolithophores during the Holocene. Moreover the increase in diatoms, radiolarians [Berger et al., 1997; Berger and Lange, 1998] and dinoflagellate cysts [Pospelova et al., 2006] during the same period in SBB support the concept of a very productive phytoplankton community. Sea level rise coupled with the reactivation of the upwelling cell off Point of Conception could explain this reinforced productivity. The BøllingAllerød interval, well laminated like the Holocene, presents moderate PP values and low organic carbon content. The Dansgaard-Oeschger $(\mathrm{D} / \mathrm{O})$ events exhibit similar characteristics (Figure 3f). Primary Production increased slightly during $\mathrm{D} / \mathrm{O}$ Interstadial 3 and 5. No significant changes were noticeable for $\mathrm{D} / \mathrm{O} 2,4$ and 6. Stable PP during most of the $\mathrm{D} / \mathrm{O}$ events was also observed in planktonic foraminifera assemblages by Hendy et al. [2002]. This new line of evidence indicates that the presence of laminated sediment in SBB is not directly due to an increased PP producing anoxia, but rather to the injection of poorly oxygenated waters in the deepest part of the basin; at least during most of the Dansgaard-Oeschger events and the Bølling-Allerød. In contrast, during the Holocene, the deposition of laminated sediments is more the result of high PP linked to the reinforcement of the upwelling cell off Point of Conception in association with the injection of poorer oxygenated waters.

\subsection{Deglaciation: Early Warming or Not?}

[31] Herbert et al. [2001] showed that on the California margin, at each of the five last glacial maxima, SST warmed up several thousand years prior to the deglaciation. For the LGM, this "early warming anomaly" is well expressed in the California borderlands region and precedes the deglaciation by 6 to $7 \mathrm{ka}$. These results are in agreement with those of Yamamoto et al. [2007]. The "early warming anomaly" is explained by a reduction of southerly transport of California Current and a stronger Southern California Countercurrent [Herbert et al., 2001]. This pattern is similar to a modern El Niño condition [Bograd and Lynn, 2001] and prevailed during the Last Glacial Maximum. On the other hand, alkenone-SST data recorded off Point of Conception [Seki et al., 2002] disagreed with this warming, as they showed a general glacial-interglacial warming starting at $18 \mathrm{ka}$. Gephyrocapsa oceanica, the tropical to subtropical species, would preferentially live in California Countercurrent warm waters, rather than in the California Current cold waters. Nowadays, this species is clearly indicative of warm waters in the SBB [De Bernardi et al., 2005] and its relative abundance in the core would then reflect the arrival warm waters in the SBB. We observed a slight increase in its percentage from 22 to $20 \mathrm{ka}$ B.P., followed by a gradual decrease until the beginning of the Bølling-Allerød warming at $\sim 15$ ka B.P. (Figure $3 \mathrm{~d}$ ). The cold species G. muellerae, probably associated with the cold California Current, exhibits low relative abundance through the same period (Figure 3e).
Our data do not suggest an intensification of the California Countercurrent, or if it is the case, to a lesser extend than that observed by Herbert et al. [2001] or Yamamoto et al. [2007]. Our results fit better with those of Seki et al. [2002] contesting an "early warming anomaly."

\subsection{Paleo-ENSO and PDO Evidence}

[32] In the Santa Barbara Basin, we assume that high relative abundance of $G$. oceanica reflects warm waters arrival and therefore is indicative of strong El Niño episodes [De Bernardi et al., 2005]. In contrast, high relative abundance of E. huxleyi tends to be indicative of non to weak El Niño conditions [Ziveri et al., 1995b]. The frequencies recorded by E. huxleyi, G. oceanica and F. profunda are comparable to those of modern ENSO and PDO (Figure 5). In the seven seasonal resolution records, spectral estimates of coccolith relative abundances show that ENSO and PDO existed for the last $28 \mathrm{Ka}$ (except for the PDO around 0.9 and 6.1 ka B.P., where the series are too short). The continuous presence of ENSO cycles during the last $28 \mathrm{ka}$ has already been proposed: Tudhope et al. [2001] deduced from annually banded corals from Papua New Guinea that ENSO had existed for the past $130 \mathrm{ka}$. They suggested that ENSO would be stronger now than at any other time over this period. Yamamoto et al. [2004] deduced from alkenone-SST data from California Borderlands, an east-west seesaw-like change, which well agreed with the long-term ENSO behavior predicted by the Zebiak-Cane ENSO model [Clement et al., 1999].

[33] During the Dansgaard-Oeschger event 3, we find the same range of periods recorded by the three species (Figure 5) as in the modern Nino3 index (Figure 2b). Consequently we can assume that ENSO operated in a "modern mode" during the Dansgaard-Oeschger event 3. A similar pattern was observed in annually laminated lake from New Zealand [Pepper et al., 2004]. During Stage 2 and early Stage 1, ENSO was operating in a different mode, as shown by the increasing periods recorded by $E$. huxleyi and $G$. oceanica from $\sim 14$ to $\sim 12.6 \mathrm{Ka}$ B.P. We estimate that strong events, for which $G$. oceanica is the marker, became less frequent through the Bølling-Allerød (Figure 5b). The relatively lower frequency of strong events has been equally observed in marine sediments off Peru [Rein et al., 2005].

[34] During the Holocene we observed an opposite trend: the periods recorded by those two species clearly decrease through the last $\sim 9 \mathrm{ka}$ (Figures $5 \mathrm{a}$ and $5 \mathrm{~b}$ ). Lower periods recorded by E. huxleyi and G. oceanica suggest that ENSO strengthens progressively from the early Holocene to present with a weak recurrence of El Niño events around $8.8 \mathrm{ka}$ and a progressive reestablishment toward modern El Niño conditions around $0.9 \mathrm{ka}$ B.P. This trend was observed in other paleoclimate records from Peru [Sandweiss et al., 1996; Rein et al., 2005], Ecuador [Rodbell et al., 1999; Moy et al., 2002], Galapagos Island [Riedinger et al., 2002], western Pacific [Tudhope et al., 2001; Cobb et al., 2003] and New England [Rittenour et al., 2000]. Another study in the SBB [Friddell et al., 2003] demonstrated that Holocene climatic variability including possibly ENSO and PDO intensified when climate was warmest. This is particularly true for the period extending from the mid-Holocene to the late 


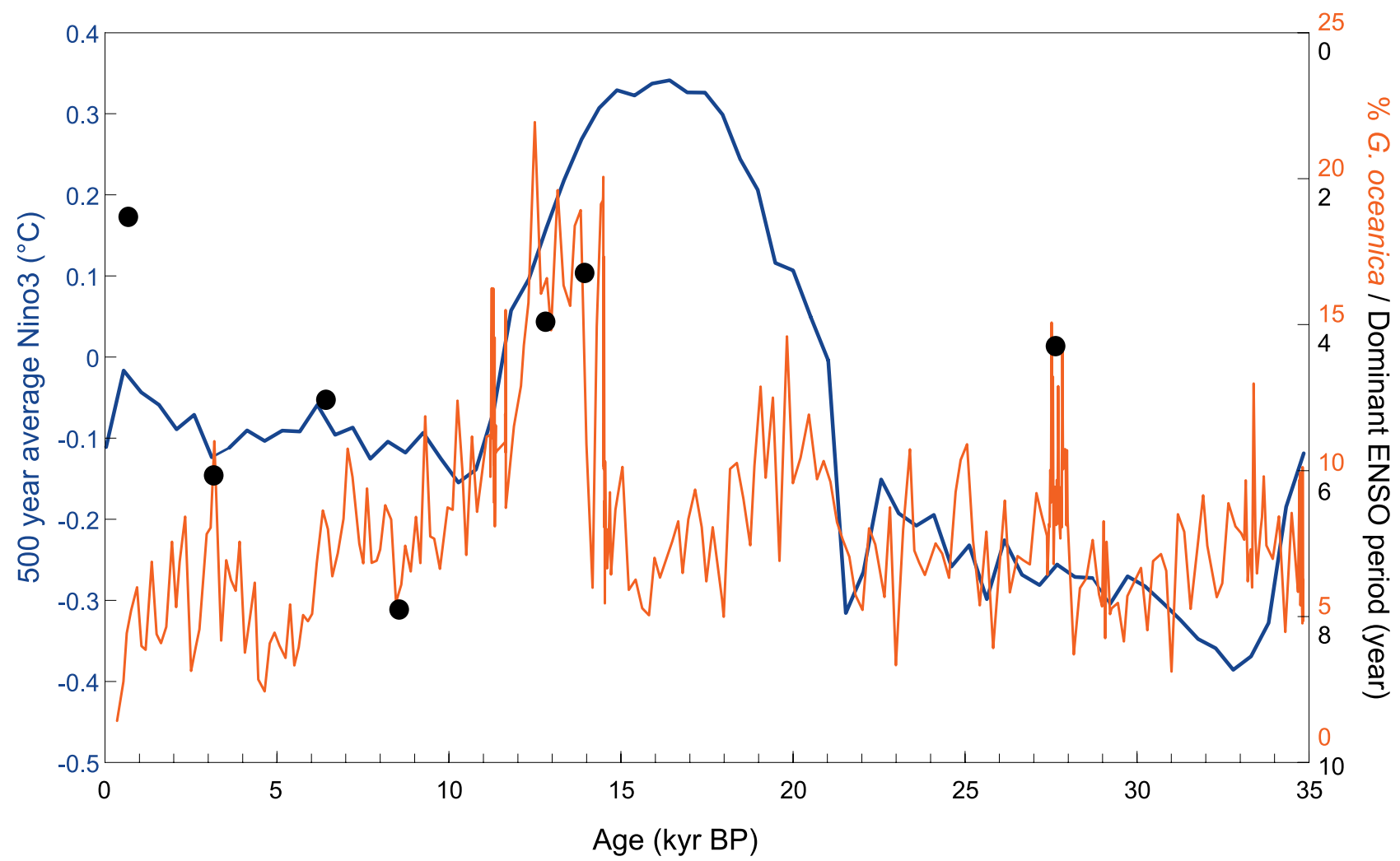

Figure 6. Blue curve, 500 year average Nino3 $\left({ }^{\circ} \mathrm{C}\right)$ from Clement et al. [1999]; red curve, relative abundance of $G$. oceanica for the last $35 \mathrm{ka}$ in core MD02-2503; black dots; the dominant ENSO period recorded by $G$. oceanica in the seven high-resolution series. These two data sets are plotted on the left $y$ axis but at two different scales.

Holocene. Moreover, Nederbragt and Thurow [2005] found similar frequencies in varve thickness variation of ODP site 893 than those we obtained from G. oceanica, during the Bølling-Allerød and the Holocene.

[35] PDO and ENSO pseudo periodicities appear to be recorded during the last $28 \mathrm{ka}$ by $F$. profunda (Figure $5 \mathrm{c}$ ), since the relative abundance of $F$. profunda depends on that of E. huxleyi. For that reason, the periods recorded by $F$. profunda may not be directly related to ENSO.

[36] It should be noted that the evolution of the periodicities recorded by E. huxleyi and $G$. oceanica seems to follow that of the precession (Figures 5a and 5b). El Niño events appear to have been less recurrent when the precession was minimal, as during the early Holocene: the periodicities, in the ENSO band, were higher than at any other time. Conversely, El Niño events appear to have been more frequent when the precession was maximal as during the late Holocene. This confirmed the ENSO evolution (weak ENSO in the early to mid-Holocene to strong and variable ENSO today) described by Clement et al. [1999, 2000].

[37] SBB sediment trap analysis revealed that the variation of the abundance of $G$. oceanica is an indicator of strong El Niño event [De Bernardi et al., 2005]. Thus, \% of $G$. oceanica can be used as a tracer of paleo-ENSO intensity. In the ENSO frequency band ( $2-7$ years), the periods where these frequencies dominate in the $G$. oceanica seasonal records appears to match the $\%$ of $G$. oceanica centennial record (Figure 6). This indicates that the intensity and frequency of El Niño vary together. During D/O3, high abundances of $G$. oceanica in the centennial record and the high frequencies of strong El Niño in the seasonal record are both indicative of the presence and the recurrence of strong ENSO events. This is contradictory to evidence of "Super La Niña" during interstadials as revealed by studies in the western Pacific [Stott et al., 2002] and on the Baja California Margin [Ortiz et al., 2004]. These studies are rather based on long-term salinity reconstruction and organic carbon burial, than on El Niño frequency. The concept of "Super La Niña" is based on mean state variations. ENSO frequency reconstruction during $\mathrm{D} / \mathrm{O} 3$ presented here indicates that El Niño events were too frequent for a "Super La Niña" state.

[38] Long-term PP seems to be disconnected from ENSO dynamics. Instead long-term PP variability in SBB appears to be related to regional (e.g., position of the Aleutian lows) and global climate dynamics than to ENSO and PDO. For example the abrupt PP increase at $11.5 \mathrm{Ka}$ B.P. is not related to a dramatic change in ENSO dynamics. Although the frequency of El Niño recurrences is diminished by a factor of two between 12.5 and $9 \mathrm{Ka}$ B.P., its intensity decreased gradually during that time interval as shown by the gradual decrease of the $\%$ of $G$. oceanica (Figure 6 ). This is not the case for PP which exhibits a sharp and rapid increase around 11.5 $\mathrm{Ka}$ and remained high during the entire Holocene. 
El Niño intensity could have been partly controlled by tropical climate variability since numerical modeling estimates of precession driven ENSO [Clement et al., 1999] and the relative abundance of $G$. oceanica are generally in good agreement. Nevertheless, during the last glacial maximum colder waters seemed to have reduced the abundance of this species (Figure 6).

\section{Conclusions}

[39] Our results suggest that the seasonality of E. huxleyi and $F$. profunda is preserved and can be extracted from the laminated sediments of the Santa Barbara Basin but remains debatable for G. oceanica. Furthermore primary production, estimated from the abundance and the diversity of coccolithophore assemblages, follows the glacial-interglacial cycle. Oligotrophic conditions prevailed prior to 11.5 ka B.P. while more eutrophic conditions settled during the Holocene. This is probably linked to whether or not the upwelling cell off Point of Conception was active. If the Dansgaard-Oeschger events and the Bølling-Allerød are correctly identified by the presence of laminations in MD02-2503, the low productivity during these warm climatic intervals suggest that laminations preservation is likely related to the injection of poorly oxygenated water in the deepest part of the basin, than an increased productivity. Our data agree with a gradual warming observed by Seki et al. [2002] during the LGM. The "early warming anomaly" observed by Herbert et al. [2001] or Yamamoto et al. [2007] is not supported by the assemblage data.

[40] This paper highlights that the two main climatic phenomena affecting the Pacific Ocean, ENSO and PDO, were active in the Santa Barbara Basin for the last $28 \mathrm{ka}$ B.P. They influenced coccolithophore assemblages during all seven periods investigated. ENSO characteristics varied during that time. ENSO exhibits a modern signature during the Dansgaard-Oeschger event 3, excluding a "Super La Niña" state. ENSO was weaker and less recurrent at the end of the Bølling-Allerød, the early and mid-Holocene. ENSO frequency increased slightly at the end of the Holocene. PDO was also recorded in coccolith assemblages of the five longest series and exhibited the same characteristics as modern PDO. Finally, we demonstrate that precession influenced the evolution of El Niño by changing the frequency of the phenomenon and probably its intensity as proposed by Clement et al. [1999, 2000].

[41] Acknowledgments. Comments by two anonymous reviewers, W. A. Berggren, and C. Pailles improved the manuscript considerably. We thank the Institut Paul Emile Victor (IPEV) for financial and technical support for the Marion-Dufresne coring during the IMAGES VIII (MONA) cruise. Funds for this study were provided by the French Agence Nationale de la Recherche program award ANR-05 PICC.

\section{References}

Andruleit, H. A., and K. H. Baumann (1998), History of the Last Deglaciation and Holocene in the Nordic seas as revealed by coccolithophore assemblages, Mar. Micropaleontol. 35(3-4), 179-201, doi:10.1016/S03778398(98)00021-8

Andruleit, H., and U. Rogalla (2002), Coccolithophores in surface sediments of the Arabian Sea in relation to environmental gradients in surface waters, Mar. Geol., 186(3-4), 505526, doi:10.1016/S0025-3227(02)00312-2.

Andruleit, H. A., U. von Rad, A. Bruns, and V. Ittekkot (2000), Coccolithophore fluxes from sediment traps in the northeastern Arabian Sea off Pakistan, Mar. Micropaleontol. $38(3-4), 285-308$, doi:10.1016/S03778398(00)00007-4.

Andruleit, H., S. Stager, U. Rogalla, and P. Cepek (2003), Living coccolithophores in the northern Arabian Sea: Ecological tolerances and environmental control, Mar. Micropaleontol., 49(1-2), 157-181, doi:10.1016 S0377-8398(03)00049-5.

Barron, J. A., L. Heusser, T. Herbert, and M. Lyle (2003), High-resolution climatic evolution of coastal northern California during the past 16,000 years, Paleoceanography, 18(1), 1020, doi:10.1029/2002PA000768.

Beaufort, L. (2002), Cruise Report MD 126 MONA VIII, 453 pp., Inst. Paul-Emile Victor, Plouzané, France.

Beaufort, L., and D. Dollfus (2004), Automatic recognition of coccoliths by dynamical neural networks, Mar. Micropaleontol., 51(1-2), 57-73, doi:10.1016/j.marmicro.2003.09.003.

Beaufort, L., and S. Heussner (2001), Seasonal dynamics of calcareous nannoplankton on a west European continental margin: The Bay of Biscay, Mar. Micropaleontol., 43(1-2), 27-55, doi:10.1016/S0377-8398(01)00020-2.
Beaufort, L., Y. Lancelot, P. Camberlin, O. Cayre, E. Vincent, F. Bassinot, and L. Labeyrie (1997) Insolation cycles as a major control of equatorial Indian Ocean primary production, Science, 278(5342), 1451-1454, doi:10.1126/science.278.5342.1451.

Behl, R. J. (1995), Sedimentary facies and sedimentology of the late Quaternary Santa Barbara Basin, Site 893, Proc. Ocean Drill. Program Sci. Results, 146, 295-305.

Behl, R. J., and J. P. Kennett (1996), Brief interstadial events in the Santa Barbara basin, NE Pacific, during the past $60 \mathrm{kyr}$, Nature, 379(6562), 243-246, doi:10.1038/379243a0.

Berger, W. H., and C. B. Lange (1998), Silica depletion in the thermocline of the glacial North Pacific: Corollaries and implications, Deep Sea Res., Part II, 45(8-9), 1885-1904 doi:10.1016/S0967-0645(98)80021-0.

Berger, W. H., C. B. Lange, and A. Weinheimer (1997), Silica depletion of the thermocline in the eastern North Pacific during glacial conditions: Clues from Ocean Drilling Program Site 893, Santa Barbara basin, California, Geology, 25(7), 619-622, doi:10.1130/0091-7613 (1997)025<0619:SDOTTI $>2.3 . \mathrm{CO} ; 2$.

Black, D. E., R. C. Thunell, and E. J. Tappa (2001), Planktonic foraminiferal response to the 1997-1998 El Niño: A sediment-trap record from the Santa Barbara Basin, Geology, 29(12), 1075-1078, doi:10.1130/0091-7613(2001) 029<1075:PFRTTE $>2.0$. CO;2

Blanchet, C. L. (2006), Variabilités climatique et océanique du dernier cycle glaciaireinterglaciaire. Propriétés magnetiques et géochimiques des sédiments de la marge NordOuest américaine subtropicale, Ph.D. thesis, p. 296, IUniv. de Droit, dEcon. et des Sci. Paul Cézanne (Aix-Marseille III), Aix-en-Provence, France.
Bograd, S. J., and R. J. Lynn (2001), Physicalbiological coupling in the California Current during the 1997-99 El Niño-La Niña cycle, Geophys. Res. Lett., 28(2), 275-278, doi:10.1029/2000GL012047.

Bollmann, J. (1997), Morphology and biogeography of Gephyrocapsa coccoliths in Holocene sediments, Mar. Micropaleontol., 29(3-4), $319-350$, doi:10.1016/S0377-8398(96) 00028-X.

Brand, L. E. (1994), Physiological ecology of marine coccolithophores, in Coccolithophores, edited by A. Winters and W. G. Siesser, pp. 39-49, Cambridge Univ. Press, Cambridge, U. K.

Broerse, A. (2000), Coccolithophore export production in selected ocean environments: Seasonality, biogeography, carbonate production, Ph.D. thesis, p. 185, Vrije Univ., Amsterdam.

Brown, C. W., and J. A. Yoder (1994), Coccolithophorid blooms in the global ocean, J. Geophys. Res., 99(C4), 7467-7482, doi:10.1029/93JC02156.

Cane, M. A. (2004), El Niño in history: Storming through the ages, J. World Hist., 15(1), 87-88, doi:10.1353/jwh.2004.0004.

Cane, M. A., and S. E. Zebiak (1985), A theory for El-Niño and the Southern Oscillation, Science, 228(4703), 1085-1087, doi:10.1126/ science.228.4703.1085.

Clement, A. C., R. Seager, and M. A. Cane (1999), Orbital controls on the El Niño/ Southern Oscillation and the tropical climate, Paleoceanography, 14(4), 441-456, doi:10.1029/1999PA900013.

Clement, A. C., R. Seager, and M. A. Cane (2000), Suppression of El Niño during the mid-Holocene by changes in the Earths orbit, Paleoceanography, 15(6), 731-737, doi:10.1029/1999PA000466. 
Cobb, K. M., C. D. Charles, H. Cheng, and R. L. Edwards (2003), El Niño/Southern Oscillation and tropical Pacific climate during the last millennium, Nature, 424(6946), 271-276, doi:10.1038/nature01779.

Dean, W. E. (2007), Sediment geochemical records of productivity and oxygen depletion along the margin of western North America during the past 60,000 years: Teleconnections with Greenland Ice and the Cariaco Basin, Quat. Sci. Rev., 26(1-2), 98-114, doi:10.1016/j.quascirev.2006.08.006.

De Bernardi, B., P. Ziveri, E. Erba, and R. C. Thunell (2005), Coccolithophore export production during the 1997-1998 El Niño event in Santa Barbara Basin (California), Mar. Micropaleontol., 55(1-2), 107-125, doi:10.1016/j.marmicro.2005.02.003.

Dollfus, D., and L. Beaufort (1999), Fat neural network for recognition of position-normalised objects, Neural Networks, 12(3), 553-560, doi:10.1016/S0893-6080(99)00011-8.

Doose, H., F. G. Prahl, and M. W. Lyle (1997), Biomarker temperature estimates for modern and last glacial surface waters of the California Current system between $33^{\circ}$ and $42^{\circ} \mathrm{N}$, Paleoceanography, 12(4), 615-622, doi:10.1029/97PA00821.

Flores, J. A., F. J. Sierro, G. Francés, A. Vázquez, and I. Zamarreño (1997), The last 100,000 years in the western Mediterranean: Sea surface water and frontal dynamics as revealed by coccolithophores, Mar. Micropaleontol., 29(3-4), 351-366, doi:10.1016/S03778398(96)00029-1.

Friddell, J. E., R. C. Thunell, T. P. Guilderson, and M. Kashgarian (2003), Increased northeast Pacific climatic variability during the warm middle Holocene, Geophys. Res. Lett., 30(11), 1560, doi:10.1029/2002GL016834.

Gardner, J. V., and P. Dartnell (1995), Centennialscale late Quaternary stratigraphies of carbonate and organic carbon from Santa Barbara basin, ODP Hole 893A and their paleoceanographic significance, Proc. Ocean Drill. Program Sci. Results, 146, Part 2, 103-124.

Gardner, J. V., W. E. Dean, and P. Dartnell (1997), Biogenic sedimentation beneath the California Current system for the past $30 \mathrm{kyr}$ and its paleoceanographic significance, Paleoceanography, 12(2), 207-225, doi:10.1029 96PA03567.

Giraudeau, J. (1992), Distribution of recent nannofossils beneath the Benguela system: Southwest African continental margin, Mar Geol., 108(2), 219-237, doi:10.1016/00253227(92)90174-G

Giraudeau, J., P. M. S. Monteiro, and K Nikodemus (1993), Distribution and malformation of living coccolithophores in the northern Benguela upwelling system off Namibia, Mar. Micropaleontol., 22(1-2), 93-110, doi:10.1016/0377-8398(93)90005-I.

Graham, N. E., and W. B. White (1988), The El-Niño Cycle: A natural oscillator of the Pacific ocean-atmosphere system, Science, 240(4857), 1293-1302, doi:10.1126 science.240.4857.1293.

Grootes, P. M., and M. Stuiver (1997), Oxygen 18/16 variability in Greenland snow and ice with $10^{-3}$ to $10^{5}$-year time resolution, $J$. Geophys. Res., 102 (C12), 26,455-26,470, doi:10.1029/97JC00880

Haidar, A. T., and H. R. Thierstein (2001), Coccolithophore dynamics off Bermuda (N Atlantic), Deep Sea Res., Part II, 48(8-9), 1925-1956, doi:10.1016/S0967-0645 (00)00169-7.
Harms, S., and C. D. Winant (1998), Characteristic patterns of the circulation in the Santa Barbara Channel, J. Geophys. Res., 103(C2), 3041-3065, doi:10.1029/97JC02393.

Hendershott, M. C., and C. D. Winant (1996), Surface circulation in the Santa Barbara Channel, Oceanography, 9, 114-121.

Hendy, I. L., J. P. Kennett, E. B. Roark, and B. L. Ingram (2002), Apparent synchroneity of submillennial scale climate events between Greenland and Santa Barbara Basin, California from 30 -10 ka, Ouat. Sci. Rev., 21(10), 1167-1184, doi:10.1016/S0277-3791(01)00138-X

Hendy, I. L., T. F. Pedersen, J. P. Kennett, and R. Tada (2004), Intermittent existence of a southern Californian upwelling cell during submillennial climate change of the last $60 \mathrm{kyr}$, Paleoceanography, 19, PA3007, doi:10.1029/ 2003PA000965.

Herbert, T. D., J. D. Schuffert, D. Andreasen, L. Heusser, M. Lyle, A. Mix, A. C. Ravelo, L. D. Stott, and J. C. Herguera (2001), Collapse of the California Current during glacial maxima linked to climate change on land, Science, 293(5527), 71-76, doi:10.1126/science. 1059209

Hill, T. M., J. P. Kennett, D. K. Pak, R. J. Behl, C. Robert, and L. Beaufort (2006), Pre-Bolling warming in Santa Barbara Basin, California: Surface and intermediate water records of early deglacial warmth, Quat. Sci. Rev., 25(21-22), 2835 -2845, doi:10.1016/j.quascirev.2006. 03.012 .

Holligan, P. M., et al. (1993), A biogeochemical study of the coccolithophore, Emiliania huxleyi, in the North Atlantic, Global Biogeochem Cycles, 7(4), 879-900, doi:10.1029/ 93GB01731.

Houghton, S. D., and M. V. S. Guptha (1991), Monsoonal and fertility controls on recen marginal sea and continental-shelf coccolith assemblages from the western Pacific and northern Indian oceans, Mar. Geol., 97(3-4), 251-259, doi:10.1016/0025-3227(91) 90119-O.

Kaplan, A., M. A. Cane, Y. Kushnir, A. C. Clement, M. B. Blumenthal, and B. Rajagopalan (1998), Analyses of global sea surface temperature 1856-1991, J. Geophys. Res., 103(C9), 18,567-18,589, doi:10.1029/97JC01736

Kennett, J. P., and B. L. Ingram (1995a), A 20,000 year record of ocean circulation and climate change from the Santa Barbara Basin, Nature, 377(6549), 510-514, doi:10.1038/ $377510 \mathrm{a} 0$

Kennett, J. P., and B. L. Ingram (1995b), Paleoclimatic evolution of Santa Barbara basin during the last 20 kyr: Marine evidence from Hole 893A, Proc. Ocean Drill. Program Sci. Results, 146, Part 2, 309-325.

Kincaid, E., R. C. Thunell, J. Le, C. B. Lange, A. L. Weinheimer, and F. M. H. Reid (2000), Planktonic foraminiferal fluxes in the Santa Barbara Basin: Response to seasonal and interannual hydrographic changes, Deep Sea Res. Part II, 47(5-6), 1157-1176, doi:10.1016/ S0967-0645(99)00140-X.

Kinkel, H., K. H. Baumann, and M. Cepek (2000), Coccolithophores in the equatoria Atlantic Ocean: Response to seasonal and Late Quaternary surface water variability, Mar. Micropaleontol., 39(1-4), 87-112, doi:10.1016/S0377-8398(00)00016-5.

Knappertsbusch, M., M. Y. Cortes, and H. R. Thierstein (1997), Morphologic variability of the coccolithophorid Calcidiscus leptoporus in the plankton, surface sediments and from the Early Pleistocene, Mar. Micropaleontol.,
$30(4), 293-317$, doi: $10.1016 / \mathrm{S} 0377$ 8398(96)00053-9.

Lange, C. B., A. L. Weinheimer, F. M. H. Reid, and R. C. Thunell (1997), Temporal sedimentation patterns of diatoms, radiolarians and silicoflagellates in Santa Barbara Basin, California, Calif. Coop. Oceanic Fish. Invest., $38,161-170$.

Laskar, J. (1990), The chaotic motion of the solar system: A numerical estimate of the size of the chaotic zones, Icarus, 88(2), 266-291, doi:10.1016/0019-1035(90)90084-M.

Longhurst, A. R. (1998), Ecological Geography of the Sea, 398 pp., Academic, San Diego, Calif

Lyle, M., M. Mix, A. C. Ravelo, D. Andreasen, L. Heusser, and A. Olivareza (2000), Millennialscale $\mathrm{CaCO}_{3}$ and $\mathrm{C}_{\text {org }}$ events along the northern and central California margins: Stratigraphy and origins, Proc. Ocean Drill. Program Sci. Results, 167, 163-182.

Malinverno, E., P. Ziveri, and C. Corselli (2003), Coccolithophorid distribution in the Ionian Sea and its relationship to eastern Mediterranean circulation during late fall to early winter 1997, J. Geophys. Res., 108(C9), 8115, doi:10.1029/2002JC001346.

Mantua, N. J., and S. R. Hare (2002), The Pacific decadal oscillation, J. Oceanogr., 58(1), 35 44, doi:10.1023/A:1015820616384.

Mantua, N. J., S. R. Hare, Y. Zhang, J. M. Wallace, and R. C. Francis (1997), A Pacific interdecada climate oscillation with impacts on salmon production, Bull. Am. Meteorol. Soc., 78(6), 1069 1079, doi:10.1175/1520-0477(1997) 078<1069:APICOW>2.0.CO;2.

McIntyre, A., and A. W. H. Be (1967), Modern coccolithophoridae of the Atlantic Ocean-I. Placoliths and cyrtoliths, Deep Sea Res. Oceanogr. Abstr., 14(5), 561-597, doi:10.1016/ 0011-7471(67)90065-4.

McIntyre, A., A. W. H. Be, and M. B. Roche (1970), Modern Pacific coccolithophoridae: A paleontological thermometer, Trans. N.Y Acad. Sci., 32(6), 720-731.

McPhaden, M. J. (1999), Genesis and evolution of the 1997-98 El Niño, Science, 283(5404), 950-954, doi:10.1126/science.283.5404.950.

Mitchellinnes, B. A., and A. Winter (1987), Coccolithophores: A major phytoplankton component in mature upwelled waters off the Cape Peninsula, South Africa in March, 1983 Mar. Biol., 95(1), 25-30, doi:10.1007/ BF00447481.

Molfino, B., and A. McIntyre (1990), Precessional forcing of nutricline dynamics in the equatorial Atlantic, Science, 249(4970), 766-769, doi:10.1126/science.249.4970.766.

Mollenhauer, G., and T. I. Eglinton (2007), Diagenetic and sedimentological controls on the composition of organic matter preserved in California Borderland Basin sediments, Limnol. Oceanogr., 52(2), 558-576.

Moy, C. M., G. O. Seltzer, D. T. Rodbell, and D. M. Anderson (2002), Variability of El Nino/Southern Oscillation activity at millennial timescales during the Holocene epoch, Nature, 420(6912), 162-165, doi:10.1038/ nature 01194

Nederbragt, A. J., and J. Thurow (2005), Amplitude of ENSO cycles in the Santa Barbara Basin, off California, during the past 15,000 years, J. Quat. Sci., 20(5), 447-456, doi:10.1002/jqs. 946.

Nederbragt, A. J., J. W. Thurow, and P. R. Bown (2008), Paleoproductivity, ventilation, and organic carbon burial in the Santa Barbara Basin (ODP Site 893, off California) since the last 
glacial, Paleoceanography, 23, PA1211, doi:10.1029/2007PA001501.

Okada, H., and S. Honjo (1973), The distribution of oceanic coccolithophorids in the Pacific, Deep Sea Res. Oceanogr. Abstr., 20, 355374, doi:10.1016/0011-7471(73)90059-4.

Okada, H., and S. Honjo (1975), Distribution of coccolithophores in marginal seas along the western Pacific Ocean and in the Red Sea, Mar. Biol., 31(3), 271-285, doi:10.1007/ BF00387154.

Okada, H., and M. Matsuoka (1996), Lowerphotic nannoflora as an indicator of the late Quaternary monsoonal palaeo-record in the tropical Indian Ocean, in Microfossils and Oceanic Environments, edited by J. A. Moguilesky and R. Whatley, pp. 231-245, Aberystwyth, Aberystwyth, U. K.

Okada, H., and A. McIntyre (1979), Seasonal distribution of modern coccolithophores in the western North Atlantic Ocean, Mar. Biol. 54(4), 319-328, doi:10.1007/BF00395438.

Ortiz, J. D., S. B. O'Connell, J. DelViscio, W. Dean, J. D. Carriquiry, T. Marchitto, Y. Zheng, and A. van Geen (2004), Enhanced marine productivity off western North America during warm climate intervals of the past $52 \mathrm{ky}$, Geology, 32(6), 521-524, doi:10.1130/ G20234.1.

Paillard, D., L. Labeyrie, and P. Yiou (1996), Macintosh program performs time-series analysis, Eos Trans. AGU, 77(39), 379 , doi:10.1029/96EO00259.

Pepper, A. C., J. Shulmeister, D. C. Nobes, and P. A. Augustinus (2004), Possible ENSO signals prior to the Last Glacial Maximum, during the last deglaciation and the early Holocene, from New Zealand, Geophys. Res. Lett., 31, L15206, doi:10.1029/ 2004GL020236.

Philander, S. G. H. (1983), El-Nino Southern Oscillation phenomena, Nature, 302(5906), 295-301, doi:10.1038/302295a0.

Pospelova, V., T. F. Pedersen, and A. de Vernal (2006), Dinoflagellate cysts as indicators of climatic and oceanographic changes during the past $40 \mathrm{kyr}$ in the Santa Barbara Basin, southern California, Paleoceanography, 21, PA2010, doi:10.1029/2005PA001251.

Reid, F. M. H. (1980), Coccolithophorids of the North Pacific Central Gyre with notes on their vertical and seasonal distribution, Micropaleontology, 26(2), 151-176, doi: $10.2307 / 1485436$

Rein, B., A. Lückge, L. Reinhard, F. Sirocko, A. Wolf, and W. C. Dullo (2005), El Niño variability off Peru during the last 20,000 years, Paleoceanography, 20, PA4003, doi:10.1029/2004PA001099.

Reynolds, R. W., N. A. Rayner, T. M. Smith, D. C. Stokes, and W. Q. Wang (2002), An improved in situ and satellite SST analysis for climate, J. Clim., 15(13), 1609-1625, doi:10.1175/ $1520-0442(2002) 015<1609$ : AIIS AS > 2.0. $\mathrm{CO} ; 2$.

Riedinger, M. A., M. Steinitz-Kannan, W. M. Last, and M. Brenner (2002), A $\sim 6100{ }^{14} \mathrm{C}$ yr record of El Niño activity from the Galapagos Islands, J. Paleolimnol., 27(1), 1-7, doi:10.1023/A:1013514408468.

Rittenour, T. M., J. Brigham-Grette, and M. E. Mann (2000), El Niño-like climate teleconnections in New England during the Late Pleistocene, Science, 288(5468), 1039-1042. doi:10.1126/science.288.5468.1039.

Rodbell, D. T., G. O. Seltzer, D. M. Anderson, M. B. Abbott, D. B. Enfield, and J. H. Newman (1999), An 15,000-year record of El Niño- driven alluviation in southwestern Ecuador, Science, 283(5401), 516-520, doi:10.1126/ science. 283.5401.516.

Roth, P. H., and W. T. Coulbourn (1982), Floral and solution patterns of coccoliths in surface sediments of the North Pacific, Mar. Micropaleontol., 7(1), 1-52, doi:10.1016/03778398(82)90014-7.

Samtleben, C., and A. Schroder (1992), Living coccolithophore communities in the Norwegian Greenland Sea and their record in sediments, Mar. Micropaleontol., 19(4), 333-354, doi:10.1016/0377-8398(92)90037-K.

Sandweiss, D. H., J. B. Richardson III, E. J. Reitz, and H. B. Rollins (1996), Geoarchaeological evidence from Peru for a 5000 years B.P. onset of El Niño, Science, 273(5281) 1531-1533, doi:10.1126/science.273.5281. 1531.

Schulz, M., and M. Mudelsee (2002), REDFIT: Estimating red-noise spectra directly from unevenly spaced paleoclimatic time series, Comput. Geosci., 28(3), 421-426, doi:10.1016/S0098-3004(01)00044-9.

Schulz, M., and K. Stattegger (1997), SPECTRUM: Spectral analysis of unevenly spaced paleoclimatic time series, Comput. Geosci., 23(9), 929-945, doi:10.1016/S00983004(97)00087-3.

Seki, O., R. Ishiwatari, and K. Matsumoto (2002), Millennial climate oscillations in NE Pacific surface waters, Geophys. Res. Lett. 29(23), 2144, doi:10.1029/2002GL015200.

Shipe, R. F., U. Passow, M. A. Brzezinski, W. M. Graham, D. K. Pak, D. A. Siegel, and A. L. Alldredge (2002), Effects of the 1997-98 El Nino on seasonal variations in suspended and sinking particles in the Santa Barbara basin, Prog. Oceanogr., 54(1-4), 105-127, doi:10.1016/S0079-6611(02)00045-9.

Smith, T. M., and R. W. Reynolds (2003), Extended reconstruction of global sea surface temperatures based on COADS data (18541997), J. Clim., 16(10), 1495-1510.

Soutar, A., and P. A. Crill (1977), Sedimentation and climatic patterns in the Santa Barbara Basin during the 19th and 20th centuries, Geol. Soc. Am. Bull., 88, 1161-1172, doi:10.1130/ $0016-7606(1977) 88<1161: \mathrm{SACPIT}>$ 2.0.CO;2.

Stott, L., C. Poulsen, S. Lund, and R. Thunell (2002), Super ENSO and global climate oscillations at millennial time scales, Science, 297(5579), 222-226, doi:10.1126 science. 1071627

Stuiver, M., and P. J. Reimer (1986), A computer program for radiocarbon age calibration, Radiocarbon, 28(2B), 1022-1030.

Takahashi, K., and H. Okada (2000), Environmental control on the biogeography of modern coccolithophores in the southeastern Indian Ocean offshore of Western Australia, Mar Micropaleontol., 39(1-4), 73-86, doi:10.1016/S0377-8398(00)00015-3.

Tanaka, Y., and R. Tada (2000), Data report: calcareous nannofossil assemblages of the last 27 K. Y. in hole 1017E, Santa Lucia Slope, off Point Conception, Proc. Ocean Drill. Program Sci. Results, 167, 303-308.

Thouveny, N., E. Moreno, D. Delanghe, L. Candon, Y. Lancelot, and N. J. Shackleton (2000), Rock magnetic detection of distal ice-rafted debries: Clue for the identification of Heinrich layers on the Portuguese margin, Earth Planet. Sci. Lett., 180(1-2), 61-75, doi:10.1016/ S0012-821X(00)00155-2.

Thunell, R. C., E. Tappa, and D. M. Anderson (1995), Sediment fluxes and varve formation in Santa Barbara Basin, offshore California, Geology, 23(12), 1083-1086, doi:10.1130/ 0091-7613(1995)023<1083:SFAVFI $>$ 2.3.CO;2.

Tudhope, A. W., C. O. Chilcott, M. T. McCulloch, E. R. Cook, J. Chappell, R. M. Ellam, D. W. Lea, J. M. Lough, and G. B. Shimmield (2001) Variability in the El Niño-Southern Oscillation through a glacial-interglacial cycle, Science, 291(5508), 1511-1517, doi:10.1126/science. 1057969.

van Geen, A., Y. Zheng, J. M. Bernhard, K. G. Cannariato, J. Carriquiry, W. E. Dean, B. W. Eakins, J. D. Ortiz, and J. Pike (2003), On the preservation of laminated sediments along the western margin of North America, Paleoceanography, 18(4), 1098, doi:10.1029/ 2003PA000911.

Vautard, R., and M. Ghil (1989), Singular spectrum analysis in nonlinear dynamics, with applications to paleoclimatic time series, Physica D 35(3), 395-424, doi:10.1016/0167-2789 (89)90077-8.

Woodruff, S. D., H. F. Diaz, J. D. Elms, and S. J. Worley (1998), COADS Release 2 data and metadata enhancements for improvements of marine surface flux fields, Phys. Chem. Earth, 23(5-6), 517-526, doi:10.1016/S0079-1946 (98)00064-0.

Yamamoto, M., T. Oba, J. Shimamune, and T. Ueshima (2004), Orbital-scale anti-phase variation of sea surface temperature in mid-latitude North Pacific margins during the last 145,000 years, Geophys. Res. Lett., 31(16), L16311, doi:10.1029/2004GL020138.

Yamamoto, M., M. Yamamuro, and Y. Tanaka (2007), The California current system during the last 136,000 years: Response of the North Pacific High to precessional forcing, Quat. Sci. Rev., 26(3-4), 405-414, doi:10.1016/ j.quascirev.2006.07.014.

Young, J. R. (1994), Functions of coccoliths, in Coccolithophores, edited by A. Winters and W. G. Siesser, pp. 63-82, Cambridge Univ. Press, Cambridge, U. K.

Zebiak, S. E., and M. A. Cane (1987), A model El-Niño Southern Oscillation, Mon. Weather Rev., 115(10), 2262-2278, doi:10.1175/ 1520-0493(1987)115<2262:AMENO >2.0. $\mathrm{CO} ; 2$.

Zhang, Y., J. M. Wallace, and D. S. Battisti (1997), ENSO-like interdecadal variability: 1900-93, J. Clim., 10(5), 1004-1020, doi: $10.1175 / 1520-0442(1997) 010<$ 1004:ELIV>2.0.CO;2.

Ziveri, P., R. C. Thunell, and D. Rio (1995a), Export production of coccolithophores in an upwelling region: Results from San Pedro Basin, Southern California Borderlands, Mar. Micropaleontol., 24(3-4), 335-358, doi:10.1016/0377-8398(94)00017-H.

Ziveri, P., R. C. Thunell, and D. Rio (1995b), Seasonal changes in coccolithophore densities in the southern California Bight during 1991 1992, Deep Sea Res., Part I, 42(11 - 12), 881 903, doi:10.1016/0967-0637(95)00089-5.

L. Beaufort, N. Buchet, and M. Grelaud, CEREGE, CNRS, Université Aix Marseille, Europôle méditerranéen de l'Arbois, BP80, F-13545 Aix-en-Provence CEDEX 4, France. (grelaud@cerege.fr)

S. Cuven, INRS-ETE, Université du Québec, 490 rue de la Couronne, Québec, QC G1K 9A9, Canada. 